Ensayo

(Essay)

\title{
AUGUSTE GHIESBREGHT'S NATURAL HISTORY EXPLORATIONS IN OAXACA AND OTHER PARTS OF MEXICO UNTIL 1854
}

\section{EXPLORACIONES DE HISTORIA NATURAL POR AUGUSTE GHIESBREGHT EN OAXACA Y OTRAS PARTES DE MÉXICO HASTA 1854}

\author{
BEAT SCHÄTTI, $, 1, *$ IVAN INEICH, ${ }^{2} \&$ CHRISTOPH KUCHARZEWSKI ${ }^{3}$
}

\author{
${ }^{1}$ Apartado postal 9, San Pedro Pochutla, Oaxaca 70900, México; <beatschaetti@hotmail.com> \\ ${ }^{2}$ Département de Systématique et Evolution (Reptiles), Muséum National d'Histoire Naturelle, CNRS UMR \\ 7205 (Origine, Structure et Evolution de la Biodiversité), case courrier n 30, 25 rue Cuvier, 75005 Paris, France; \\ <ineich@mnhn.fr> \\ ${ }^{3}$ Museum für Naturkunde, Leibniz-Institut für Evolutions- und Biodiversitätsforschung, Invalidenstr. 43, 10115 \\ Berlin, Germany; <c.kucharzewski@mfn-berlin.de> \\ * Corresponding author: <beatschaetti@hotmail.com>
}

Recibido: 05/04/2017; aceptado: 19/09/2017; publicado en línea: 16/03/2018

Editor responsable: Gustavo Aguirre

Schätti, B., Ineich, I., \& Kucharzewski, C. (2018) Auguste Ghiesbreght's natural history explorations in Oaxaca and other parts of Mexico until 1854. Acta Zoológica Mexicana (n.s), 34(1), 1-22.

\begin{abstract}
The authors review the zoological and botanical collections by Auguste Ghiesbreght from "Oaxaca" and other areas between 1838 and 1854. Taxonomically relevant are, for instance, the holotype of the Racer Coryphodon oaxaca Jan (Coluber constrictor L.), one of various amphibian and reptile species (coll. Ghiesbreght) not on record for Oaxaca, or a number of birds from southern Mexico implicitly attributed to Ghiesbreght but in fact gathered by other collectors. Zoological items and a plethora of plants from "Oaxaca" (coll. 18411854) encompassing many type specimens were obtained elsewhere, in particular the inland Gulf region between Hidalgo and the Orizaba Range. These results entail consequences regarding type localities or distribution, and possibly systematics, in different animal groups and botanical fields.
\end{abstract}

Key words: Amphibians, reptiles, birds, invertebrates, plants, distribution, type specimens, systematics.

\section{INTRODUCTION}

Our interest in Boniface Augustin Lucien, called Auguste, Ghiesbreght (1812-1893) arose from amphibians and reptiles reputedly collected in Oaxaca, and in particular the disputed origin of the holotype of Coryphodon oaxaca
Schätti, B., Ineich, I. y Kucharzewski, C. (2018) Exploraciones de historia natural por Auguste Ghiesbreght en Oaxaca y otras partes de México hasta 1854. Acta Zoológica Mexicana (n.s), 34(1), $1-22$.

RESUMEN. Los autores revisan las colecciones de historia natural hechas por Auguste Ghiesbreght de "Oaxaca" y otras áreas entre 1838 y 1854. Especímenes de relevancia taxonómica son por ejemplo el holotipo de la 'corredora' Coryphodon oaxaca Jan (Coluber constrictor L.), una entre varias especies de anfibios y reptiles (col. Ghiesbreght) no registradas en el Estado de Oaxaca, o bien algunas aves de México meridional atribuidas implícitamente a Ghiesbreght pero en realidad recolectadas por otros naturalistas. Material zoológico y una multitud de plantas de "Oaxaca" (col. 1841-1854) incluyendo muchos especímenes tipo provienen de otras partes y particularmente de las regiones interiores del Golfo de México desde Hidalgo hasta el área del Pico de Orizaba. Estos resultados tienen consecuencias respecto a localidades tipo, distribución y posiblemente la sistemática en diferentes grupos de animales y campos de la botánica.

Palabras clave: anfibios, reptiles, aves, invertebrados, plantas, distribución, tipos, sistemática.

Jan, 1863, a Racer (Coluber constrictor oaxaca) described from "Mexique" but obtained in the eponymous state according to contemporary French herpetologists (e.g., Duméril et al., 1854a, see Table 1).

Auguste Ghiesbreght was gathering plants, animals, and other natural history items in Mexico for more than 
Table 1. MNHN-RA amphibians and reptiles reputedly collected by Auguste Ghiesbreght in "Oaxaca": Verbatim registration in catalogue of acquisitions, taxon and accession number of respective specimen or series (type status if applicable), and early published records.

\begin{tabular}{|c|c|c|}
\hline Ledger entry & identity & reference(s) \\
\hline \multicolumn{3}{|c|}{$\begin{array}{l}1842 \text { - “d'Oaxaca, au Mexique" from M.[onsieur] "Ghuisbreght" [sic] - amphibians (Hylidae, Plethodontidae) and lizards } \\
\text { (Phrynosomatidae) }\end{array}$} \\
\hline "Geotriton mexicanus" & $\begin{array}{l}\text { Pseudoeurycea gadovii (Dunn, 1926) } \\
\text { MNHN-RA } 4749 \text { (five specimens) }\end{array}$ & $\begin{array}{l}\text { Duméril, Bibron \& Duméril (1854c: } 94 \text { f., Pl. } \\
\text { 104, Bolitoglossa mexicana), all five "Oaxaca" } \\
\text { specimens without type status ("peut-être [...] autre } \\
\text { espèce") }\end{array}$ \\
\hline "Tropidolepis variabilis seu aeneus" & $\begin{array}{l}\text { Sceloporus variabilis Wiegmann, } 1834 \\
\text { MNHN-RA } 3056 \text { (two specimens) }\end{array}$ & $\begin{array}{l}\text { Duméril \& Duméril (1851: 77, T.[ropidolepis] } \\
\text { variabilis), "Oaxaca: M. Ghuisbreght" }\end{array}$ \\
\hline "Microlepidotus (Tropidolepis)", & $\begin{array}{l}\text { S. grammicus microlepidotus Wiegmann, } 1828 \\
\text { MNHN-RA } 3152 \text { (six specimens) }\end{array}$ & $\begin{array}{l}\text { Duméril \& Duméril (1851: 77, Tr. Microlepidotus), } \\
\text { "Oaxaca (Mexique): M. Ghuisbreght"; Duméril } \\
\text { (1856: 548), "du Mexique par [...] M. Ghuisbreght" }\end{array}$ \\
\hline "Dipsas nebulosa" & $\begin{array}{l}\text { Sibon dimidiatus (Günther, 1872) } \\
\text { MNHN-RA } 7297\end{array}$ & $\begin{array}{l}\text { Duméril et al. (1854a: 468, Petalognathus } \\
\text { nebulatus (Linnaeus, 1758)), "Mexique [...] Variété } \\
\text { D [...] par [...] Ghuisbreght"; Mocquard (1908: } \\
\text { 882), see text }\end{array}$ \\
\hline "Lycodon?” & specific allocation and specimen (1) unknown & see text \\
\hline "Psammophis?" & $\begin{array}{l}\text { Coluber constrictor oaxaca (Jan, 1863) MNHN- } \\
\text { RA } 7378 \text { (holotype) }\end{array}$ & $\begin{array}{l}\text { Duméril et al. (1854a: 184, Coryphodon } \\
\text { constrictor (Linnaeus, 1758)), "d'Oaxaca, par M. } \\
\text { Ghuisbreght"; Jan (1863: 63), "Mexique"; Bocourt } \\
\text { (1890: 697, 701-02, Pl. 48.2, Bascanion oaxaca), } \\
\text { "rapporté d'Oaxaca (Mexique)", see text }\end{array}$ \\
\hline "Saurien voisin du G. ${ }^{\text {re }}$ Polychrus" & $\begin{array}{l}\text { Laemanctus serratus Cope, } 1864 \\
\text { MNHN-RA } 2094\end{array}$ & $\begin{array}{l}\text { Duméril \& Duméril (1851: 55) and Duméril (1856: } \\
\text { 512, Pl. XXI.4, “près de la ville d'Oaxaca", in } \\
\text { error), as L. longipes (Wiegmann, 1834), see text }\end{array}$ \\
\hline "Aphobérophide" & $\begin{array}{l}\text { Conophis lineatus (Duméril, Bibron \& D., 1854) } \\
\text { MNHN-RA } 3740 \text { (paralectotype) }\end{array}$ & $\begin{array}{l}\text { Duméril et al. (1854b: 938, Pl. 73.1-4, Tomodon } \\
\text { lineatum), "du Mexique"; Jan \& Sordelli (1866: Pl. } \\
\text { 6.3); Bocourt (1876: 407), "recueillis à Oaxaca, par } \\
\text { [...] Ghiesbreght"; Bocourt (1886: 644, Pl. 38.5, } \\
\text { Conophis lineatus), see text }\end{array}$ \\
\hline "Dendrophis?" & specific allocation and specimen (1) unknown & see text \\
\hline
\end{tabular}

fifty years and "was perhaps the botanist with the greatest knowledge of the flora of northern Mesoamerica during the first half of the XIX century" (Ossenbach, 2009). One bizarre souvenir is a skull erroneously attributed to Moctezuma II (Comas 1967), the Aztec emperor M. Xo- coyotzin who ruled when Hernán Cortés conquered his capital in 1519 .

Surprisingly little is known about Ghiesbreght's travelling in the country where he spent most of his life, and biographies (Rovirosa, 1889; Silvestre, 2014) basically 
attest a blank as to details such as his specific movements and whereabouts in the forties and early fifties of the nineteenth century. Casas-Andreu (1996) does not quote the collector at all and Flores-Villela's et al. (2004) sketch of the herpetological exploration of Mexico, to cite an example, dedicates "Ghiesbrecht" a single mention in a short parenthesis, prompting our quest for the collector's activities, and in the first place within Oaxaca State.

\section{SOURCES AND MATERIAL}

José Narciso Rovirosa-Andrade's essay on Auguste Ghiesbreght is based on notes by the biographer's friend "el Lic. Pánfilo Grajales", a former (1882) major of San Cristóbal Las Casas [sic], and help received from the leading concurrent Mexican plant taxonomist José Ramírez. Britton (1890) formulated an English summary of Rovirosa's (1889) publication. The bulk of information on the Belgian expedition to Mexico and Ghiesbreght exposed in Possemiers (1993b), Ceulemans (2006), Diagre (2011: 89, 95-96), and Silvestre's (2014) exhaustive study regarding the Benelux relies upon documents in official archives, mostly covering the period from 1837 to 1840 , as well as contemporary newspaper articles. Ghiesbreght's diary, however, only exists in the present authors' flights of fancy and the English translation of Ceulemans (2006); the original French edition merely avers the accounts of one of his companions in Mexico ("les récits de Funck") [Nota 1].

José Rovirosa never met the profiled man and some episodes are unsubstantiated, for example Ghiesbreght's doctor degree in Paris at young age or his military career as a surgeon in the aftermath of the 'Night of the Opera' on August 25, 1830, viz. the Belgian secession from the United Kingdom of the Netherlands (Silvestre, 2014). Relevant within our primary time horizon (1838-1854) are the fictive leave for a short visit to Europe in summer 1839 and the 1840 shipping of the collections erroneously dated in spring ("Marzo"). Three unspecified traverses from the Gulf to the Pacific and the ascent of various volcanoes between Jalisco and Oaxaca ("cruzó por tres veces la gran cordillera [...] y ascendió á los volcanes de Colima, Jorullo y Cempoaltepec") appear not to be quite accurate as to these summits and the mountaineer. Rather, Frederik Michael Liebmann visited the peak of Cerro Zempoaltepec and, at the same time (i.e., September 1842), our protagonist collected on Cerro Zempoala (“Sempoala", MNHN-P 430498-99) near Huauchinango in N Puebla (Fig. 1, see The "Oaxaca” Issue). For the rest, a few of Rovirosa's (1889) minutiae are inaccurate, for instance the date of Ghiesbreght, Linden, and Funck's disembarkation at Veracruz allegedly at the beginning of January (" 8 de Enero") 1838 or the former's voyage to Europe in "1857" (1856) [Nota 2].

Admittedly, information for larger periods in Ghiesbreght's life is virtually inexistent and most evidence has vanished in the mist of time, all but impossible to bring to light. According to his passport fetched on September 8, 1835, he was tall $(170 \mathrm{~cm})$ for that time, had auburn hair, and blue eyes (Silvestre, 2014: 144). The richly illustrated homage of Jean Linden by a fourth generation descendant (Ceulemans, 2006) does not show his field mate in Brazil and Mexico or later provider of living plants for his business, and an inquiry among the Council of Horticultural and Botanical Libraries neither resulted in a portrait of Ghiesbreght.

On-sight investigations did not uncover yet unknown personal data of this singular man except the death certificate in the civil registry of San Cristóbal de las Casas. The bachelor "Doctor Agustin Ghiesbreght" died on March 7, 1893 at 7 pm in his home of Santa Lucía neighbourhood by apoplexy. The body was entombed in the mausoleum of José Joaquín Peña, seemingly an intimate. That cemetery has disappeared and no new vault of this liberal lawyer, politician, and journalist could be found in today's packed San Cristóbal de las Casas communal graveyard that opened in 1899.

Plants from "Ciudad-Real, Cacaté, les forêts de San-Bartolo et de Jitotoli" (Chiapas) and "Santiago de Tabasco [Villahermosa], la capitale, Tcapa [Teapa] et ses forêts, les Rios Tcapa, Puyapatago et Tabasco, etc." outlined by Lasègue (1845: 213) or the fern Llavea cordifolia Lagasca, 1816 from "Chiapas pr. Amatenango" (coll. Linden) found in February (Fournier, 1872: 122) helped to establish the 1839-40 itinerary. These localities are situated in the surroundings of San Cristóbal de las Casas ("Ciudad Real", Cacaté Ixtapa, Jitotol Municipality), Venustiano Carranza ("San Bartolo") District, and the vicinity of Teapa including the Río Puyacatengo. Furthermore, memoirs of Linden (in Linden \& Planchon 1863: LXVIII-LXIX), Ghiesbreght's companion in Mexico from 1838 until summer 1840, unveil a few details of the Belgian exploration as, for example, a trip to Palenque two years after the description and illustration of those Mayan ruins by Frédéric de Waldeck. These recollections and James McKinney's testimony of "three Belgians [...] on a scientific expedition" in early 1840 (Stephens, 1841: 

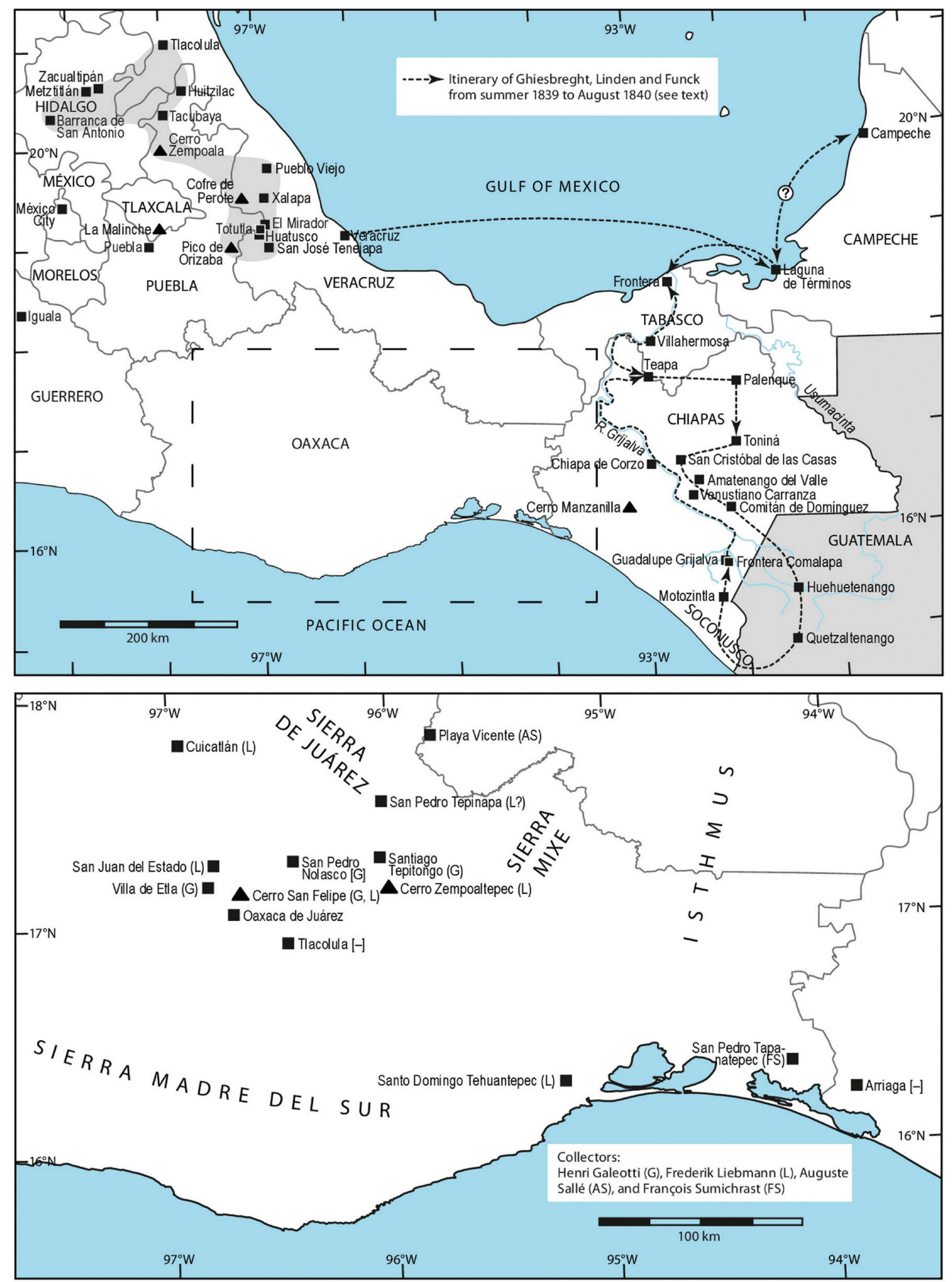

Figure 1. Localities and geographical features mentioned in the text (parts of Guerrero and area northwest to Colima not shown). Stippled area in Atlantic central Mexican highlands (Sierra Madre Oriental) shows region explored by Ghiesbreght between 1841 and September 1843. Drawing Andrea Stutz. 
250), making us understand that they clandestinely visited archaeological sites, allow a fair approximation of the route in southern Mexico and Guatemala (see next chapter, Fig. 1) [Nota 3].

Data regarding Ghiesbreght's life in Mexico after 1840 expounded hereafter largely relies upon his correspondence with influential members of the Paris Museum between 1842 and summer 1854, viz. Adolphe-Théodore Brongniart ("Monsieur Brogniart" or "Brogniard", eight letters), the father of paleobotany, and the head of horticulture Joseph Decaisne (September 12, 1849). These lines composed at different places including Coscomatepec southwest of Totutla and Pueblo Viejo in Veracruz (October 1844 and May 1845, resp.) or "Tajimaroa" in Michoacán (Ciudad Hidalgo, April 1852) reveal details of the collector's personal situation, projects, and areas or localities visited. Other annotations refer to certain shipments of plants to Brongniart. We learn, for example, that Ghiesbreght was planning an expedition to California, which he never achieved due to the lack of sponsoring or the war with the United States of America (1846-48), and that he was working on an unspecified and never published contribution to the Mexican flora. In mid-October 1849 , he gave a "vivid description of his journeys through Mexico" (Ossenbach, 2007: 186, footnote 10) to another leading botanist of that time, Charles François Antoine Morren in Liège. Unfortunately, a pdf-archive of this letter got astray "through a server failure" resulting in the loss of records (C. Ossenbach in litt.), and we could not locate the original document nor a few other letters (see next chapter).

Most specimens mentioned on the following pages (coll. A. B. Ghiesbreght [ABG], "Ghiesbrecht", "Ghisbrecht", "Ghisbreght", "Ghuisbreght", or "Guisbreght") are deposited in the Institut royal des Sciences naturelles de Belgique, Bruxelles (Brussels, IRSNB) and the Muséum national d'Histoire naturelle in Paris (MNHN). BMNH denotes The Natural History Museum, London (former British Museum, Natural History), $\mathrm{K}$ is short for Kew Royal Gardens, and USNH stands for the United States National Herbarium (Smithsonian Institution, Washington D.C.). Ghiesbreght's correspondence with Brongniart is filed in the botanical library of the Paris Museum (MNHN-P), and the Institut de France holds his 1849 letter to Decaisne (Ms. 2445/XX/97-98). In the case of bird taxonomy, we follow http://avibase.bsc-eoc.org (accessed December 2016) except for Pipilo cf. torquatus Du Bus, the Collared Towhee (van Rossem 1940), "an obvious hybrid” (IRSNB 3043, holotype) [Nota 4].
Information regarding vertebrate specimens housed in the IRSNB is deplorably incomplete. With respect to fishes, amphibians, reptiles or mammals, we do not know whether any material exists at all in the IRSNB, and cannot corroborate a single voucher in the Brussels collections attributed to Ghiesbreght's Mexican field mates Linden and Funck between 1838 and 1840. We achieved to procure some general records from the bird and type registers. However, detailed requests for specific additional data did not produce any reply as to the collectors (or numbers) of holdings such as, for instance, a male paratype of Aphelocoma unicolor Du Bus, 1847 and a couple of Euphonia elegantissima (Bonaparte, 1838) from "S. Pedro" in Oaxaca (Du Bus, 1846), nor the provenance of the holotype of Arremon [Chlorospingus flavopectus] ophthalmicus Du Bus, 1847 and various syntypes of Euphonia [Chlorophonia] occipitalis Du Bus, 1847 [Nota 5].

\section{LIFE IN MEXICO}

Auguste Ghiesbreght first came into contact with the New World and its flora and fauna as a member of the Belgian expedition to Brazil between end of 1835 and beginning of December 1836. Consequently, King Leopold I commissioned the botanist and entrepreneur Jean Linden, twenty-one years old draughtsman Nicolas Funck, and Ghiesbreght to explore Central America and Colombia (e.g., Anonymous, 1837). They embarked at The Hague in October 1837 and reached Havana fifty days later. The halt on Cuba, plagued by yellow fever, prolonged and in January 1838 , a royal envoy on his way to Mexico brought instructions that compelled the three voyagers to accept modification of plans and join that diplomatic mission. They may not have been very amused to learn about their new destination, due to the raising tensions between Mexico and France.

A dozen cases comprised of roughly 150 living plants collected during the three month-stay on the island were dispatched from Havana under the auspices of the Belgian Ministry of Interior in late February 1838. According to Rovirosa (1889), Ghiesbreght and his friends received orders from Prime Minister ("primer ministro plenipotenciario belga") de Norman. In reality, Baron Félix de Norman, landlord and Major of Westmalle in Flanders with a longing for transatlantic projects, was an emissary of Leopold I in search of fortune. It was fairly frivolous to launch into that venture precisely when foreigners includ- 
ing diplomatic personnel were about to leave Mexico because of the looming Pastry or First Franco-Mexican War (1838-39) which had its origin in a looted French-owned confectioner shop in Mexico City.

In March 1838, the naturalists and de Norman's entourage arrived at Veracruz (Linden \& Planchon, 1863, see Notae 1-2). They marched to the capital via Xalapa where the party rested for a week and explored the outskirts. The sojourn in Mexico City demanded patience from the academic team until it received the necessary endorsement for travelling and field work issued by the Secretary of Foreign Relations and signed by Anastasio Bustamante, the President of the Republic (Rovirosa, 1889). A cargo of nine wooden boxes and crates with botanical and zoological collections left Veracruz on June 15, 1838 but was lost in the Pastry War blockade (e.g., Possemiers, 1993b).

Formally in charge of zoological aspects and in distinguished company, Ghiesbreght ascended the Pico de Orizaba (5636 m asl), the third highest North American summit, in August 1838. Another alpinist present on that occasion was the French-Belgian botanist and geologist Henri Guillaume Galeotti. A comment by the latter narrates an entire year spent with Ghiesbreght in Veracruz and what he called the Mexican plains ("une année avec M. A. Ghiesbreght dans les forêts de Xalapa et dans les plaines de Mexico", Martens \& Galeotti, 1843: 213), namely the Central Plateau from around Mexico City ("le plateau d'Anahuac", Linden \& Planchon, 1863) to the Orizaba area, the vicinity of Huatusco in the interior highlands of central Veracruz near the border with Puebla (e.g., Cofre de Perote), and all along the Gulf versant ("tout le versant oriental de la Cordillère", 1.c.), possibly as far north as Hidalgo. Galeotti's annotation alludes to the period roughly between spring 1838 and April 1839 (Lasègue, 1845: 211, 215).

Ghiesbreght's (1839) letter relating the time spent between the Orizaba area and their operation centre at El Mirador (see below) where he penned the lines ends with the hope that the French blockade may soon come to a term and the expectation of subsequent collecting in Oaxaca. This endeavour, however, seems never have become a reality. Linden (in Linden \& Planchon, 1863) notes that they sailed from Veracruz to Campeche ("s'embarquèrent à la Vera-Cruz pour Campêche"), perhaps directly to Laguna de Términos and not the state capital. It was in summer 1839 when Linden fell severely sick with amarillic typhus, and the mission stayed put for three months (1.c.). By sea, the Belgians returned to Tabasco (Frontera) around October. They rested a moment near Villahermosa before roaming the outskirts of Teapa for a good while until the end of the year (Rovirosa, 1889), probably preparing the cargo of living plants to be picked up in July (see below) [Nota 6].

Passing through Tabasco and Chiapas, the Belgian expedition penetrated into adjacent Guatemala. In July 1840 , and with rich collections aboard (fourteen containers fide Silvestre, 2014), Funck and Ghiesbreght departed by boat from Guadalupe Grijalva in Frontera Comalapa Municipality (Chiapas) via Teapa to Europe (Fig. 1). Linden set forth to Tabasco and Havana the following month and made for the United States prior to returning home. Together with his companions, he had "formed by far the largest collections we have seen from those parts of Mexico" (Hemsley 1887) [Nota 7].

Literally, Linden (in Linden \& Planchon, 1863) averred that they had entered the highlands of Chiapas, made an excursion into what he described as northern Guatemala, and returned through the Soconusco along the so-called South Sea (Pacific) coast ("ils explorèrent ensuite les régions élevées [...] de Chiapas, pénétrèrent dans la partie septentrionale du Guatemala [...], et revinrent sur le golfe du Mexique, en appuyant vers le Soconusco et les côtes de la mer du Sud"). Given the departure from Teapa not earlier than towards the end of 1839, the unnavigable Usumacinta or mention of the Lacandon rainforest ("territoire des Indiens Locandones"), locality records of their collections or visits of Palenque and nearby Mayan ruins ("Ocosingo", viz. Toniná, see preceding chapter), and the naturalists' presence in the Upper Río Grijalva (Linden, 1.c.: "Guadalupe de Frontera") near the border with Guatemala before the end of July 1840 (Silvestre, 2014), there can hardly be reasonable doubt that Funck, Ghiesbreght, and Linden passed over San Cristóbal de las Casas and Comitán de Domínguez into Totonicapán-Huehuetenango (Guatemala). The territory in the latter country alluded to in Linden's recollections is the western portion of today's Guatemala as far east as the departments of Quiché, Sololá, and Suchitepéquez as well as Soconusco Province. Most certainly, the Belgians crossed the Sierra Madre of Chiapas above Motozintla on their way towards Frontera Comalapa (Fig. 1) [Nota 8].

Ghiesbreght spent five months (October 1840 until March 1841) in Belgium and France and left the old continent aboard the metaphorical vessel Flore, this time at his own expense. He arrived in Veracruz on May 13 after a horrific voyage (L'Observateur August 18, 1841, reproduced in Silvestre, 2014: 146-47). Ghiesbreght was 
supposed to gather geographic data for Philippe Vandermaelen (see Silvestre 2016: 338) and collected plants on behalf of Belgian horticulturists such as Louis Van Houtte, Henri Galeotti, and eventually Jean Linden (e.g., Morren, 1857), or natural history items in general commanded by the museums in Brussels and Paris. Private collectors including the avid Hugh Cuming acquired, for instance, snail shells today mostly housed in the BMNH (see Notae 14 and 22). However, specifics of Ghiesbreght's life between 1841 and 1854, when he resided mainly in Mexico City (fide Rovirosa, 1889), are poorly documented.

After the westward crossing of the Atlantic, Ghiesbreght apparently pitched headquarters at Carl Christian ("Carlos") Sartorius's Hacienda El Mirador close to Totutla. The generous host, committed to natural history himself, collected "at every opportunity" plants, today deposited in the USNH (Hemsley, 1887), or for example herpetological material (Flores-Villela et al., 2004). El Mirador was the place of encounter and veritable fulcrum for European travellers and naturalists, and that is where our protagonist first met Frederik Liebmann. This botanist, passionate collector of amphibians and reptiles, later director of the Copenhague Botanical Garden, and editor of the Fauna Danica had arrived in early 1841 and ascended the Pico de Orizaba at the beginning of September in company of Ghiesbreght (Liebmann, 1869). Relevant in our context is their last, and certainly prolonged, reunion at El Mirador after the Dane's return from Oaxaca (see last chapter).

In 1842 and the following year, Ghiesbreght visited Hidalgo, the northern corner of Puebla, and central Veracruz. In September and early November 1842, he supervised the clearing of two consignments for Paris in the City of Veracruz, and spent at least a couple of days in Mexico City around mid-December. From September until the beginning of December 1843, Ghiesbreght trekked beyond the Sierra Madre del Sur ("la grande Cordellière [sic] et au-delà", L'Observateur May 1 ${ }^{\text {st }}, 1844$, see Silvestre 2014: 148, note 819), probably in Guerrero (Acapulco area), and fell sick as a consequence. This resulted in limited hunting and the suspension of shipments to Europe for the rest of 1844. Field work in Guerrero as early as in "1842" implied by, for example, a Bletia adenocarpa Reichenbach, 1856 (MNHN-P 430326, ABG 66) from the vicinity of Iguala or another orchid with a much higher field number (MNHN-P 484734, ABG 265) gathered in the same general area ("terre tempérée de la Cordillère entre Acapulco et Mexico") is simply an impossibility (see above).
An untraceable letter to Linden in Venezuela, supposedly written in 1844, relays the grief of Carmencita desperately longing for Linden's return (Ceulemans, 2006). However, we do not know how Ghiesbreght learnt about the young Creole beauty's solitude and whether his words testify a recent visit to Teapa and reunion with their 1839 host, namely the girl's seemingly wealthy father. Another equally vague pointer is a vicious assault by brigands near Puebla in "1846" (fide Rovirosa, 1889).

Specimens (ABG) from Michoacán (e.g., MNHN-P 623856, Apatzingán) were collected from 1845 onwards. Orchids from unspecified places in this state (1849-50) or the central Mexican Pacific versant (1853) including northern Guerrero (Du Buysson, 1878: 203, 409, 431) date from as late as into the next decade (e.g., Morren, 1857). Ghiesbreght's presence in Michoacán over a certain period (1852-53) is corroborated by letters to Brongniart. A strong hint that the collector had ties with compatriots operating business there are the late summer 1849 lines to Decaisne penned in the house of "J. Keymolen", a relative of the contentious Belgian consul (Louis K.) at Mexico City. Two plants from Colima (MNHN-P 624895-96) farther northwest along the Pacific versant were probably gathered during an expedition in the midforties [Nota 9].

It seems that Ghiesbreght had suspended the search for orchids, bromeliads, etc. towards 1850 because of private motives and reasons beyond his control such as, after war with the northern neighbour (1846-48), the raging cholera epidemic of 1848-1850. In the long term, however, this was contrary to his gusto and neither risk nor danger could deter him from answering the call of passion for nature as he put it in letters to Brongniart. After an interruption of several years, the collector re-established relations with the MNHN in summer 1852.

In 1855, Ghiesbreght took up residence in Teapa and returned to Europe the following year, for the first time since March 1841 (see Note 7 and Silvestre 2014: 149, note 822). The passengers' list of the Porta-Coeli reproduced in a Mexican newspaper (Anonymous 1856) affirms the arrival of "Augusto Ghiesbreght" in Veracruz from Le Havre (departure August 30).

After a longer stay at Hacienda La Bellota of Manuel Jamet on the Tabasco coast in 1862, Ghiesbreght made for a journey to San Cristóbal de las Casas that same summer (Rovirosa, 1889). From November 1862 until his death, "D.[on] Agustín, el Naturalista" as he was known among locals (Rovirosa 1893: 72), lived in that South Mexican highland city and then Chiapanecan capi- 
tal. There, he helped the community in matters such as the determination of the town's elevation (Anonymous, 1886) and did not tire of providing medical service for the poor. An obituary of Ghiesbreght appeared, for example, in a Mexico City based English newspaper (Anonymous, 1893a).

\section{AMPHIBIANS AND REPTILES FROM "OAXACA"}

Two lots composed of a total of twenty-seven specimens purportedly from Oaxaca were purchased from Auguste Ghiesbreght and incorporated into the collection of the Muséum national d'Histoire naturelle (MNHN) at the very beginning of August 1842 and in October 1845, respectively. They belong to twelve species, viz. two amphibian, three lizard, and seven snake taxa. Except in the case of the untraceable "Tropidonotus saurita" series, ophidians are represented by single specimens, and two among them ("Lycodon ?" and "Dendrophis ?") cannot be located for the time being (Table 1). They may be destroyed or are possibly lost (see last paragraph of chapter) [Nota 10].

Given the systematic concept, generic allocations, and higher rank terminology used by the then head of the herpetology and ichthyology department (e.g., Duméril \& Bibron, 1844; Duméril et al., 1854b: p. I, "Serpents opisthoglyphes ou Aphobérophides"), the latter family name denotes the back-fanged Conophis lineatus (Duméril, Bibron \& Duméril, 1854), and we tentatively identify "Psammophis ?" with Coluber constrictor oaxaca (Jan, $1863)$. In the case of the systematically problematical Oaxacan Milk Snake (Lampropeltis Fitzinger, 1843), we follow recent local contributions (e.g., Mata-Silva et al., 2015; Schätti \& Stutz, 2016) and refer the species in question to L. cf. polyzona Cope, 1860 [Nota 11].

The catalogue of acquisitions gives no individual locality data for Ghiesbreght's 1842 and 1845 lots, although the corytophanid lizard and natricid taxon were later published with more precise indications. The origin of Coryphodon oaxaca Jan is contradictory (Table 1) and Tomodon lineatus Duméril, Bibron \& Duméril was introduced without a hint to Oaxaca or the collectors (see Nota 11).

As is evident from the illustration in Duméril (1856: P1. XXI.4), a Casque-headed Basilisk ("Laemanctus longipes") from the vicinity of Oaxaca de Juárez ("près de la ville d'Oaxaca", 1.c.) belongs to L. serratus Cope, 1864.
This area above $1500 \mathrm{~m}$ asl on the Central Plateau is completely isolated from all Mexican populations at "low and moderate elevations" in Veracruz, Chiapas, and the Yucatán Peninsula (McCranie \& Köhler, 2004b). The species has never been found again in Oaxaca and the origin of MNHN-RA 2094 is indeed incorrect [Nota 12].

The wording in Duméril et al. (1854a: "recueilli à Oaxaca") regarding the provenance of at least one (i.e., that used for preparation of the skull) out of six "Tropidonotus saurita" refers to a place rather than a region, viz. the City of Oaxaca de Juárez and not the homonymic state. The proper identification of the unlocated Garter Snake series (Thamnophis Fitzinger, 1843) and individual allocations remain open to debate.

We did not unearth herpetological specimens (ABG) other than those cited in this text (1842-1854) and shipments received after 1854 probably entirely consisted of dry vouchers, basically plants and snail shells (see Discussion). Although the holotype of Coryphodon oaxaca Jan (MNHN-RA 7378) cannot be precisely assigned to one of the originally undetermined taxa, there can be no doubt that this and another type specimen (MNHN-RA 3740, Conophis lineatus) must have been received between 1842 and 1845 because both snakes present in Ghiesbreght's next (1854) delivery (Tantilla deppii, Thamnophis melanogaster, see Nota 10) are not considered in the 'Erpétologie générale' issues (vol. 7) published that same year.

Pituophis mexicanus Duméril, Bibron \& Duméril, 1854 was established upon an unknown number of individuals with unspecified origins and different provenance ("envoyée du Mexique par plusieurs voyageurs") including "Ghuisbreght" [sic], the only specified collector. Despite the lack of indication, we think that this might be MNHN-RA 3188, a fine specimen of nearly two metres total length. Morphologically, that syntype is most similar to $P$. catenifer (Blainville, 1935) differs from $P$. deppei (Duméril, Bibron \& Duméril, 1854) and clearly so visà-vis the southern highland $P$. lineaticollis (Cope, 1861) from SW Michoacán into SW Guatemala [Nota 13].

As in the case of Coryphodon oaxaca Jan (see second paragraph of chapter), we cannot positively associate Pituophis mexicanus Duméril, Bibron \& Duméril with any ledger record, and in particular material provided by Ghiesbreght (see Table 1 and Nota 10). Admittedly, it seems hard to imagine that this taxon had originally been classified as "Lycodon?" or "Dendrophis ?", viz. the supposedly missing "Oaxaca" taxa. However, it cannot be excluded that this is exactly what happened. A plausible 
explanation would be that these generic names were those attributed to the specimens by Ghiesbreght, and conveniently adopted by Gabriel Bibron when he registered the 1842 and 1845 lots (Table 1). Even under that assumption, our identification of the Racer (Coryphodon oaxaca Jan) with "Psammophis?" makes sense. Another possibility that cannot be ruled out based on the absence of data for the syntype of $P$. mexicanus among Ghiesbreght snakes consists in a confusion of the collector by Duméril et al. (1854a).

\section{DISCUSSION}

Our attempt to retrieve information on botanical and zoological items discovered by Auguste Ghiesbreght in Oaxaca State involved the examination of a large number of natural history literature and specimens. However, expectations to unearth relevant details and get a clear picture of the areas visited by this ardent and vigorous naturalist dwindled in the course of our investigation and made way to meagre results in terms of positive evidence, but not necessarily so in circumstantial findings.

Mexican natural history material obtained by Ghiesbreght prior to 1841 (e.g., Nyst, 1841) is deposited in Belgium including the IRSNB (see Sources and Material). Specimens in other European collections, mostly plants, were registered starting in 1842. That year, various departments of the Paris Museum (MNHN), for example, bought lots from Ghiesbreght (e.g., Duméril \& Bibron, 1844: p. X, "Ghuisbreght"; Papavero, 1971; McVaugh, 1972; Papavero \& Ibáñez-Bernal, 2001, see Notae 4 and 14). At the same time, the French banker, businessman, and passionate botanist Benjamin Delessert acquired Mexican plants with identical provenance (Lasègue, 1845: 211). The latter reference, one of the few to quote collecting sites other than Mexico (or "Mexique") or often incorrect origins such as "Tabasco" (see below), specifies localities (coll. "Linden") in the latter state and Chiapas ("Chiapan"), as does Rovirosa (1889) for the years after 1854.

Digitalised specimens (ABG) with useful locality data basically housed in the MNHN-P (see Nota 4) demarcate the region investigated by Ghiesbreght between January and early September 1842 and the same period in the following year. All sighted items bearing a specific origin and uncontestably gathered in 1842-43 (incl., e.g., BMNH 1045304 and K 529746 received in exchange) come from Hidalgo, far northern Puebla, and central inland Veracruz.
These series are comprised of Ghiesbreght's handwritten field labels up to $\mathrm{n}^{\circ} 124$ (presenting some minor gaps and ABG 85-105 missing) as well as 180 (e.g., MNHN-P 3897154, Figs 1-2) [Nota 14].

The only specific faunistic passage in Ghiesbreght's correspondence is the description of the content of a box with sixty-two terrestrial snails (24 spp.) on the packing list of the late 1841 shipment. Published Mexican records (ABG) appear to be absent for large insect orders (Coleoptera, Hymenoptera, Lepidoptera) or Mantodea, Odonata, and Orthoptera, as well as Arachnida and other arthropods or further invertebrate phylae other than gastropods and diptera enumerated in Nota 14 . With regard to lower vertebrates or mammals, we did not hit upon any detailed Mexican locality at all (see Sources and Material incl. Nota 5 regarding IRSNB, preceding chapter, and Nota 20).

Thirteen supposedly new species of birds from northern Mesoamerica described by Du Bus (1845-46, 1847ab), four valid taxa assigned to Bonaparte (1850) upon an unfinished manuscript by the former, a junior synonym of the White-crowned Sparrow Zonotrichia leucophrys (Spizella maxima Bonaparte, 1853), and Cyanocitta [Cyanocorax] yucantanica Dubois, 1875 are partly devoid of collecting data as noted by van Rossem (1940: "no locality $[\ldots]$ nor $[\ldots]$ original source either in the register or on the stand") in context with the male holotype of Pipilo torquatus ("No. 7391", viz. IRSNB 3043, see Nota 5).

The provenance $(A B G)$ is confirmed for ten birds with type status from Mexico including the vicinity of the "Hacienda de Mirador" or "Xalapa" in Veracruz, "Tabasco", and "Yucatan" (IRSNB 3014, 3016, 3020-21, 3031, 3034, 3051, 3091-93) and six additional items (3015, 4724, $5258,7417,7581,7581 \beta$ ) encompassing a supposed "cotype" of Buteo ghiesbreghti Du Bus, 1845. Another fourteen specimens comprising at least eleven holotypes and a paratype apparently have no data as to their collectors and it is questionable how many may have been obtained by Ghiesbreght (Appendix) [Nota 15].

Cyanocorax unicolor and Sylvia taeniata Du Bus were described from "Mexique", and the former was subsequently illustrated and reported from various places including "Tabasco" (Du Bus 1848: Pl. 17, IRSNB 3034, "Voyage Ghiesbreght" fide register, see Appendix). Nevertheless, van Rossem (1942) indicates the origin of both the Unicoloured Jay and Olive Warbler to be "Tabasco", considers their respective "type" to have been "without doubt collected by Ghiesbreght in the same locality" of Chiapas ("it is certain that Chiapas, not Tabasco, is the 


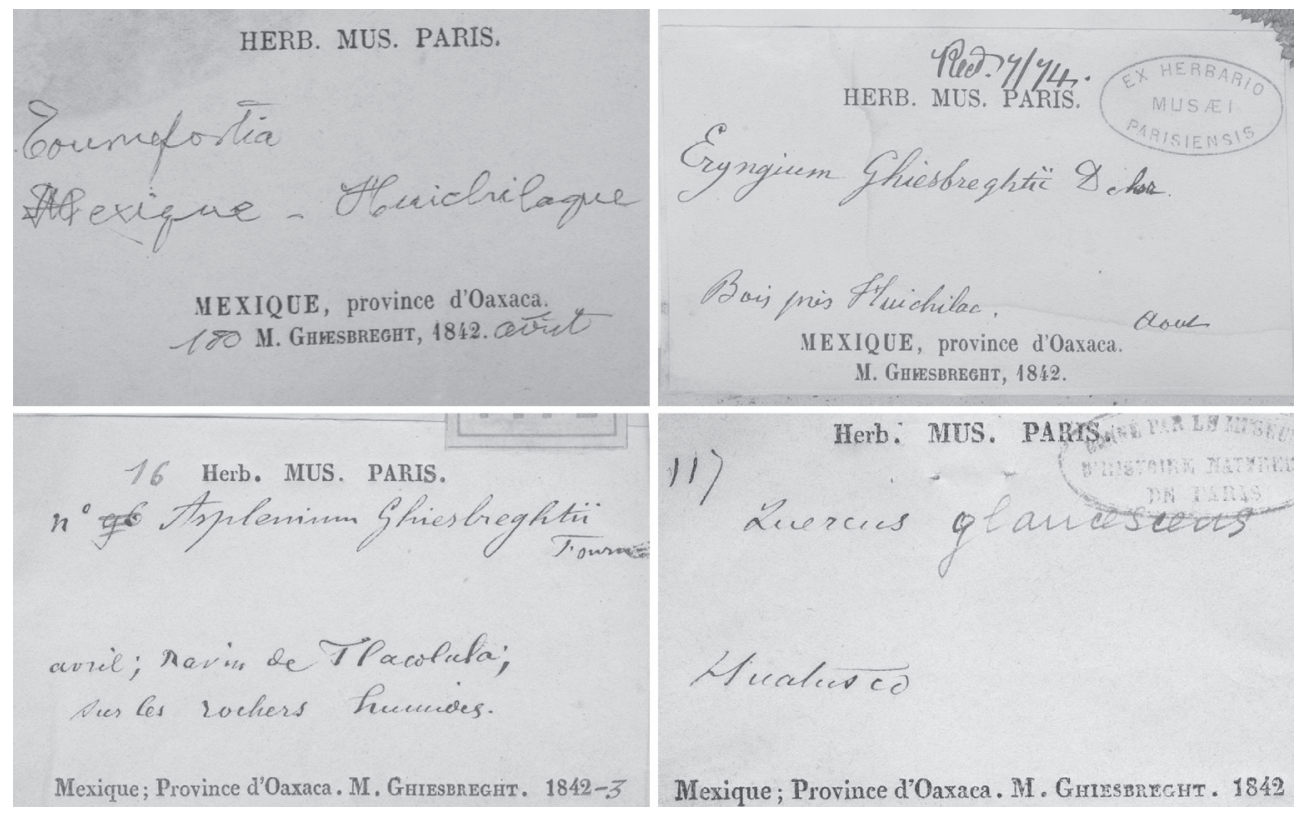

Figure 2. "Oaxaca" labels of a Tournefortia sp. (MNHN-P 3897154, upper left) and Eryngium ghiesbreghtii Decaisne, 1873 (K 529746 , upper right) from Huitzilac ("Huichilaque") in northernmost Puebla as well as Asplenium ghiesbreghtii Fournier, 1872 (MNHN-P 219954, "type", lower left) and Quercus glaucescens Kunth, 1817 (MNHN-P 754021, isotype, lower right) from Tlacolula and Huatusco, respectively, in central Veracruz (Fig. 1).

type region of both"; see Hellmayr 1934: 58, footnote 2, "The locality "Tabasco» [for C. unicolor] can hardly be correct"), and he is mistaken when stating that the former was encountered "probably in the spring of 1838 or 1839". The holotype (IRSNB 3034) of this cloud forest species was likely shot during the traverse of Chiapas in 1840 (see Life in Mexico, Nota 14 regarding Teapa area, and below as to paratypes from Oaxaca).

Nominal bird species described by Du Bus (1847a-b, 1855) from unspecified places in Mexico (except Playa Vicente) or Guatemala and definitely not collected by Ghiesbreght include Carduelis notata (Spinus notatus, IRSNB 3044, holotype, "don. Carron de Villardt 17. IV. 1855"), Cyanoloxia concreta (C. cyanoides concreta, see Nota 16), Ischnosceles niger (Geranospiza caerulescens nigra, IRSNB 3032, holotype, "Achat Verheyen 29. XI. 1847”), Monasa inornata (Malacoptila panamensis inornata, IRSNB 3047-48, syntypes, "Achat C. Dubois 27. VIII. 1847"), or Prionites carinatus (Ramphastos sulfuratus Lesson, 1830, IRSNB 3049, holotype, "Achat Dubois 27. VIII. 1847") [Nota 16].

Two "young of the year" (van Rossem, 1942) paratypes of Aphelocoma unicolor ( $̋+q$ fide Du Bus, 1848) from Oaxaca have identical origins as reported for a pair of Euphonia elegantissima ("S. Pedro", Du Bus, 1846) and a male syntype (IRSNB 3017) of Trogon collaris shot at "Tepitongo" in September 1843 (Du Bus, 1845: T. xalapensis). Du Bus (1848: footnote, "indications [...] données par la personne même qui a tué ces oiseaux") does not unveil the identity of the person who killed the two $A$. unicolor, which appears to be Henri Galeotti who sold at least the female paratype from Tepitongo (IRSNB 3035, "Achat Galeotti", see Sources and Material incl. Nota 5 regarding lack of data for three "S. Pedro" specimens incl. E. elegantissima). The collector of the trogon is unknown ("inconnu" fide register) but this paratype was likely obtained from the same provider. By all means, Galeotti shot a Middle American Saltator, Saltator coerulescens grandis (Deppe, 1830), at Tepitongo in "Sept." (Salvin, 1882: 200, year not specified) as well as a Black-throated Gray-Warbler, Setophaga nigrescens (Townsend, 1837), a male Eastern Warbling-Vireo, Vireo gilvus (Vieillot, 1807), or a female Bush Tanager, Chlorospingus flavopectus ophthalmicus (Du Bus, 1847), at "San Pedro" (Salvin, 1882: 90) or "S. Pedro" (1.c.: 112, 196) in October ( $S$. nigrescens, Ch. f. ophthalmicus) and December ( $V$. gilvus) 1844 [Nota 17].

Our brief analysis of the distribution pattern of Ghiesbreght's MNHN-RA amphibians and reptiles from "Oaxaca" (Table 1) does not take into account the unlocated 
Thamnophis sp., or different spp., nor MNHN-RA 0419 (Lampropeltis cf. polyzona). This Milk Snake belongs to a genus with disputed species concepts and would hardly contribute useful information.

The Tree Frog Smilisca baudinii inhabits Mesoamerican tropical lowlands southeast into Costa Rica whereas the False Brook Salamander Pseudoeurycea gadovii (det. David B. Wake) is confined to alpine habitats at elevations higher than $2200 \mathrm{~m}$ above sea level in Puebla, Tlaxcala, and limitrophe Veracruz, viz. the Pico de Orizaba (type locality), La Malinche, and Cofre de Perote Ranges, respectively (Solano-Zavaleta et al., 2009).

The endemic Mesquite Lizard Sceloporus grammicus extends over large parts of Mexico and is found, for instance, throughout the Oaxacan highlands. The Mesoamerican Rose-bellied Lizard S. variabilis occurs along the Gulf versant and in SE Oaxaca (Mather \& Sites, 1985; Mata-Silva et al., 2015: Table 4). The Casque-headed Basilisk Laemanctus serratus is absent from the whole state (see preceding chapter).

The Racer Coluber constrictor oaxaca is recorded from northern Mexico and the Gulf region into Guatemala (Wilson, 1978: Map). The few known collecting sites situated closest to Oaxacan territory are in the vicinity of Tierra Blanca and at the western limit of the Central Isthmus in Veracruz (Pérez-Higareda \& Smith, 1991) near the state border (Atlantic lowlands along Sierra de Juárez and S. Mixe), and Ocuilapa in W Chiapas (Smith, 1971). The presence of this taxon in Oaxaca is "inferred" (Wilson 1978) from or "implied" (Smith \& Taylor, 1945) by the scientific name and far from confirmed ("perhaps «Oaxaca»", 1.c.). Mata-Silva et al. (2015: Table 4) correctly question ("?") the occurrence of C. constrictor oaxaca in this state [Nota 18].

Within Mexico, the Mesoamerican xenodontid Conophis lineatus is reported from Jalisco, Querétaro, and Veracruz to the Yucatán Peninsula (see Wallach et al., 2014). The species occurs in the Central Isthmus at Matías Romero (Conant, 1965) and the Tehuantepec Plain (Mata-Silva et al. 2015: Table 4). Bocourt's $(1876,1886)$ mention from Oaxaca de Juárez based on Ghiesbreght's paralectotype is unsubstantiated (MNHN-RA 3740, see Table 1 and Nota 11). Highland records of "Conophis lineatus (Kennicott in Baird, 1859)" from the "Sierra Madre de Oaxaca", the "Mixteca alta", and "Valles centrales" (Casas-Andreu et al., 2004) belong to Conopsis lineata (Kennicott).

The Snaileater Sibon dimidiatus (Günther, 1872) from Veracruz to Central America occurs along the Oaxacan
Gulf versant (Kofron, 1990). It appears that nobody has ever examined MNHN-RA 7279 since Mocquard (1908) who refers Ghiesbreght's specimen to Petalognathus nebulatus (Linnaeus, 1758) and mentions various ("plusieurs") specimens lacking names of collectors and with identical origin ("Mexique") as reported by Duméril et al. (1854a).

Based on the above, we conclude that two species among Ghiesbreght's "Oaxaca” amphibians (Pseudoeurycea gadovii) and reptiles (Laemanctus serratus) are absent from this state. The Racer (Coluber constrictor oaxaca) at best enters peripheral Atlantic areas and Conophis lineatus is only documented for the Isthmus (see above and penultimate paragraph of chapter), resulting in strong reservations as to the genuine origin of specimens with the provenance "Oaxaca" (Table 1). The salamander was most likely collected between Tlaxcala and the Puebla-Veracruz border region east of the Central Plateau. As a matter of fact, both amphibian species and all systematically verified "Oaxaca" lizards and snakes (ABG) are recorded from within less than fifty kilometres between Huatusco and Xalapa (i.e., Hacienda El Mirador) encompassing altitudes from below $1000 \mathrm{~m}$ around the former town to over $4000 \mathrm{~m}$ above sea level (Fig. 1). A plethora of plants from Ghiesbreght with detailed locality data and gathered in the same period as his herpetological specimens (1841/42-1854) in fact originates from that comparatively small area (see Nota 4, Life in Mexico, and below). Higher elevations close to the Puebla border west of the capital Xalapa are also inhabited by the pinesnake Pituophis deppei, a species that potentially might have made part of the 1842 or 1845 shipment (see preceding chapter) [Nota 19].

No first-hand information is available regarding herpetological material (ABG) in the IRSNB (see Sources and Material). Werner's (1909) Crocodylus rhombifer (Cuvier, 1807) from "Mexiko" is without further published data. The malacophagous snake Leptognathus maxillaris Werner, 1909 ("No. 120") was described on the basis of a single specimen from "Tabasco, Mexico", viz. IRSNB 2026 received from Linden (“17. XI. 1857”, Lang 1990). Laurent (1949: Figs 20-22) examined and illustrated this female ("I. G. no 1939, Reg. n 3042", see Nota 5). Dipsas maxillaris (Werner) is only known from the holotype, the origin probably in error (suspected to be in South America), and the taxon possibly a synonym of $D$. elegans (Boulenger, 1896) whose type locality ("Tehuantepec", leg. Boucard 1871) is equally incorrect (Kofron, 1982: 46; Cadle, 2005: 88 incl. footnote; Schätti \& Stutz, 2016: 
nota 2). We suppose that the name-bearer of $L$. maxillaris Werner was collected during Linden's botanical explorations in Colombia and parts of Venezuela.

\section{THE “OAXACA” ISSUE}

One of our initial hypothesis conjectured a possible northwestward march of the Belgian expedition along the Chiapanecan coast in summer 1840 on their way back to the Gulf. However, the assumption must be refuted that the explorers might have entered extreme SE Oaxaca near San Pedro Tapanatepec, or having traversed the Isthmus of Tehuantepec. Nothing indicates a fastidious detour over Arriaga close to the recent Chiapas-Oaxaca border and via Chiapa de Corzo (Tuxtla Gutiérrez) far downstream of Guadalupe Grijalva, the point of embarkment. That potential route would neither have made sense nor be in line with the time schedule of the party (see Life in Mexico). Moreover, our investigations did not generate evidence for Ghiesbreght's supposed north-south passage of Oaxaca (Rovirosa, 1889). At any rate, there is no hint whatsoever as to collecting in the Tehuantepec area (Isthmus) or the contiguous Pacific coast of Oaxaca [Nota 20].

Apart from his expressed hope for collecting in "Oaxaca", once the French blockade were over, at the end of the 1830's (see Life in Mexico), we came across a single mention of this state by Ghiesbreght himself in his reply to a letter from Brongniart. These lines composed in the City of "Vera Cruz" in mid-September 1842 specify the contents of various containers sent to Paris and refer to the difference of the flowers among morphologically otherwise highly similar species of "macrobulbum orchidées" (possibly incl. Epidendron [Cyrtopodium] macrobulbon La Llave \& Lexarza, 1825) in a former "Oaxaca" cargo (“[...] envoyé $[\ldots]$ dans mon second envoi de Oaxaca"). Taking into account all available evidence and the context of the letter, there can hardly exist doubts about a lapsus calami, namely that Ghiesbreght rather meant the delivery from the Orizaba region encompassing the northwestern foothill areas (e.g., vic. Coscomatepec) probably despatched in late 1841 .

The complete lack of information on Ghiesbreght's whereabouts in Oaxaca and not a single reliable specific locality record from there inspire certain unease. Qualms as to the true origin are nourished by McVaugh's (1972) thought-provoking discovery in the Paris herbarium. This author found plenty of "printed labels, with $[\ldots]$ a line at bottom «Mexique-Province d'Oaxaca M. Ghiesbreght. 1842»" on sheets with plants from outside this state (see text, Fig. 2). Specimens "commonly bear additional handwritten labels, often with precise information as to locality of collection", for example in the case of a Crownbeard and another Sunflower species (Asteraceae) with "Oaxaca" tags but actually from Morelos. Similarly, Renner \& Hausner (2005) report the lectotype of the shrub Citriosma riparia Tulasne, 1855 (Monimiaceae), a junior synonym of Siparuna thecaphora (Poeppig \& Endlicher, 1838), from "Veracruz [«Prov. Oaxaca»]: Huatusco, 1843 (female), coll. Ghiesbrecht" [sic] [Nota 21].

The borage Ehretia tinifolia Linnaeus, 1759 from Cuicatlán ("Quicatlan", MNHN-P 3514373, ABG 58, coll. "1842") and the epiphytic orchid Rhynchostele aptera (La Llave \& Lexarza) Soto Arenas \& Salazar, 1993 from San Juan del Estado (MNHN-P 449989, n 4, "1842-3") are indeed from Oaxaca. That year, however, Ghiesbreght travelled through the Atlantic interior highlands between Hidalgo and central Veracruz. At the same time, his friend Liebmann explored the Southern Plateau between Tehuacán in SE Puebla and Oaxaca de Juárez (until end of May) including "Cuicatlan" and the "Cuesta de San Juan del Estado (9400 pieds)", viz. the northern precipice of the San Felipe Range (Cerro Peña de S. F.) close to 3000 $\mathrm{m}$ above sea level. Subsequently, this naturalist climbed the Zempoaltepec ("mont Sempoaltepec"), descended to the Pacific coast in October, visited the Tehuantepec area, and returned over the Oaxacan capital to El Mirador in January 1843 (Liebmann, 1869). There, the latter most probably ceded duplicates of his plants to Ghiesbreght whose presence at the hacienda is corroborated by, for instance, a Tillandsia pruinosa Swartz, 1797 (MNHN-P 1641216, see Life in Mexico).

The terrestrial gastropod Ampullaria eumicra Fischer \& Crosse, 1890 (lectotype MNHN-IM 2000.23082, ABG), presumably a junior synonym of Pomacea $f$. flagellata (Say, 1827), was described from Oaxaca ("in provinciâ Oajaca dictâ") and the type locality carelessly positioned near the Pacific coast (1.c.: 244, "Mexique, dans l'Etat d'Oajaca, près du Pacifique"). Apart from the immediately preceding taxon (A. innexa Fischer \& Crosse, 1890 ) with identical origin and synonymy ("Oajaca”, $P . f$. flagellata), not a single Oaxacan snail shell was received from Ghiesbreght according to Fischer \& Crosse's (1888, $1890,1893)$ indications. The introduction to the first volume of the land and sweet water molluscs (1.c. 1870: 3, 7 [table]) states that Ghiesbreght explored in particular "Oajaca" and Chiapas, but all specimens associated with 
him are exclusively reported from the latter state or, in a few instances, the southern part of Mexico ("Habitat in parte meridionali reipublicæ Mexicanæ") and "Tabasco" (p. 363). Material from Oaxaca indeed comes from other collectors including Boucard and Sallé (see Nota 15) [Nota 22].

To summarise, our search for Auguste Ghiesbreght's natural history items from "Oaxaca" produced no trustworthy locality record situated in that state. With respect to amphibians and reptiles, the salamander Pseudoeurycea gadovii is a central Mexican high altitude endemic with a restricted distribution range, the reputed presence of the basilisk Laemanctus serratus in the vicinity of the capital Oaxaca de Juárez is conclusively in error, and at least two out of eight (without Lampropeltis cf. polyzona) systematically identified species purportedly obtained in Oaxaca have never been recorded from there. Scientific specimens with that provenance may in reality hail from any region visited by the collector during the 1840 's, and in particular the Gulf draining inland versants from Hidalgo to the Orizaba Range. We strongly suppose that most, if not all, MNHN-RA herpetological material from "Oaxaca" (ABG) was in fact obtained between Huatusco, Xalapa, and the Cofre de Perote in the interior highland area of central Veracruz along the border with Puebla.

ACKNOWLEDGEMENTS. Laura Olivia Alfonzo Urbina (San Cristóbal de las Casas) and Nicole Schuermann-Ceulemans (Haelen, NL) provided information on Auguste Ghiesbreght. Andrea Stutz (Arroyo Cruz, Oaxaca) made online investigations, sighted cartographic material of three centuries, scrutinised old Mexican newspapers, struggled through weighty tomes, created the map, and read early drafts. Billy Fried (Yoshua Tree, CA) and Ingrid van Beuren (San Pedro Cholula) handled linguistic subtleties. Kraig Adler (Ithaca), Denis Diagre (Bruxelles), and Carlos Ossenbach (San José, Costa Rica) gave hints allowing to establish important contacts. John Boggan and Meghann Toner (both Washington) verified the provenance (by exchange) of Ghiesbreght specimens in, for instance, the Smithsonian Institution (USNH). Esther Jackson (New York), Jeanette McDevitt (Pittsburgh), and Marty Schlabach (Ithaca) joined our unsuccessful hunt for a portrait of the protagonist. Françoise Bérard facilitated access to the library of the Institut de France. Odile Poncy and Florence Tessier offered in-house data on plants and tracked down Ghiesbreght's correspondence in the botanical library of the MNHN. Roger Bour, Piotr Piotr Daszkiewicz, Jérôme Fuchs, and Patrice Pruvost identified handwritings in the herpetological department's ledger, procured contemporary details about internal MNHN mater or checked ichthyological and ornithological holdings. Rudolf Jenny (Berne), Gustavo A. Romero-González (Cambridge, MA), and Germán Carnevali Fernández-Concha (Mérida, Yucatán) gave advice regarding orchids, and Jon Ablett (London) and Ira Richling (Kiel) helped as to Helicina lindeni Pfeiffer.

\section{REFERENCES CITED}

Allorge, L. \& Ikor, O. (2003) La fabuleuse odyssée des plantes Les botanistes voyageurs, les Jardins des plantes, les Herbiers. JeanClaude Lattès, Paris, 727 pp.

Anonymous. (1837) Nouvelles de l'Intérieur. L'Indépendant, September 17 (édition du matin), p. 3.

Anonymous. (1856) Pasajeros del Porta-cali. El Siglo XIX, October 7, p. 4.

Anonymous. (1886) Memoria sobre la determinación de la altura absoluta del Cerro Hueitepec, presentada por el suscrito Ingeniero ["Ramírez"] del Estado. Periódico Oficial de Chiapas, September 11, p. 2.

Anonymous. (1893a) The Belgian-Mexican Savant. The Two Republics, April 14, p. 4.

Anonymous. (1893b) Notes and News [Ghiesbreght's obituary]. Botanical Gazette, 18(5): 194.

Baillon, H. (1879) Sur les ailes séminales de certaines Rubiacées. Adansonia [recueil d'observations botaniques], 12, 296-310.

Baird, S. F. (1859) Reptiles of the boundary, with notes by the naturalists of the survey. Pp. 1-36 [41 plates). In: United States and Mexican Boundary Survey, under the orders of Lieut. Col. W. H. Emory, Major First Cavalry, and United States Commissioner. Vol. 2 (pt. 2) [1858]. Government Printing Office, Washington.

Blainville, H. D. de. (1835) Description de quelques espèces de reptiles de la Californie, précedée de l'analyse d'un système generale d'herpétologie et d'amphibiologie. Nouvelles Annales du Muséum National d'Histoire Naturelle de Paris (3e sér.), 4(3), 232-296.

Bocourt, M. (1874) Études sur les reptiles et les batraciens. $3^{\text {e }}$ Livr. Pp. 113-192 [plates 16-17, 17bis, and 18 (2)]. In: A. H. Duméril, M. Bocourt \& F. Mocquard (Eds.). Mission scientifique au Mexique et dans l'Amérique Centrale (1870-1909). Recherches zoologiques. Troisième partie. $I^{\text {re }}$ section [Reptiles]. Imprimerie Nationale, Paris.

Bocourt, M. F. (1876) Notes sur quelques reptiles de l'Isthme de Tehuantepec (Mexique) données par M. Sumichrast au Muséum. Journal de Zoologie, 5, 386-411.

Bocourt, M. (1883) Études sur les reptiles et les batraciens. $9^{\mathrm{e}}$ Livr. Pp. 529-592 [plates 31-35]. In: A. H. Duméril, M. Bocourt \& F. Mocquard (Eds.). Mission scientifique au Mexique et dans l'Amérique Centrale (1870-1909). Recherches zoologiques. Troisième partie. $I^{\text {re }}$ section [Reptiles]. Imprimerie Nationale, Paris.

Bocourt, M. (1886) Études sur les reptiles et les batraciens. 10 ${ }^{\mathrm{e}}$ Livr. Pp. 593-656 [plates 36-41]. In: ibid.

Bocourt, M. (1890) Études sur les reptiles et les batraciens. $12^{\mathrm{e}}$ Livr. Pp. 697-732 [plates 25-26 and 48-51]. In: ibid.

Bonaparte, C. L. [Prince of Musignano] (1838) Descriptions of new or interesting birds from Mexico and South America. Proceedings of the Zoological Society of London, Part 5 (59) [1837], 108-114.

Bonaparte, C. L. (1850) Conspectus generum avium. Tom. I. E. J. Brill, Leiden [“Lugduna Batavorum”], [2+] 543 pp.

Bonaparte, C. L. (1853) Notes sur les collections rapportées en 1853, par M. A. Delattre, de son voyage en Californie et dans le Nicarague. Comptes rendus hebdomadaires des Séances de l'Académie des Sciences, 37(25), 913-925.

Boulenger, G. A. (1885) Catalogue of the Lizards in the British Mu- 
seum (Natural History). $2^{\text {nd }}$ ed. Vol. II. Trustees of the British Museum (Natural History), London, XIII + $495 \mathrm{pp}$.

Boulenger, G. A. (1896). Catalogue of the snakes in the British $\mathrm{Mu}$ seum (Natural History). Vol. III. Trustees of the British Museum (Natural History), London, XIV + 727 pp.

Britton, E. G. (1890) [Review of] Ghiesbreght, Augustus B. Explorador de Mexico; Veda [sic] y trabajos del Naturalista Belga. Jose N. Roriosa [sic] (La Naturaleza. i. (2d ser, pp. 211-217). Bulletin of the Torrey Botanical Club, XVII (1), 21-22.

Brocchi, M. (1881) Étude des batraciens de l'Amérique Centrale (1881-1883). $1^{\text {re }}$ Livr. Pp. 1-56 [plates I-V and IX-X]. In: A. H. Duméril, M. Bocourt \& F. Mocquard (Eds.). Mission scientifique au Mexique et dans l'Amérique Centrale (1870-1909). Recherches zoologiques. Troisième partie. $2^{e}$ section. Imprimerie Nationale, Paris.

Brocchi, M. (1883) Étude des batraciens de l'Amérique Centrale (1881-1883). $3^{\mathrm{e}}$ Livr. Pp. 97-122 [plates VII and XVI-XXII]. In: A. H. Duméril, M. Bocourt \& F. Mocquard, F. (Eds). Mission scientifique au Mexique et dans l'Amérique Centrale (1870-1909). Recherches zoologiques. Troisième partie. $2^{e}$ section. Imprimerie Nationale, Paris.

Bryson, R. W., Jr., García-Vázquez, U. O. \& Riddle, B. R. (2011) Phylogeography of Middle American gophersnakes: mixed responses to biogeographical barriers across the Mexican Transition Zone. Journal of Biogeography, 38(8), 1570-1584.

Cadle, J. E. (2005) Systematics of snakes of the Dipsas oreas complex (Colubridae: Dipsadinae) in western Ecuador and Peru with revalidation of D. elegans (Boulenger) and D. ellipsifera (Boulenger). Bulletin of the Museum of Comparative Zoology, 158(3), 67-136.

Casas-Andreu, G. (1996) Notas para la historia de los estudios herpetofaunísticos en el Estado de Oaxaca, México. Boletín de la Sociedad Herpetológica Mexicana, 7(1), 21-26.

Casas-Andreu, G., Méndez de la Cruz, F. R. \& Aguilar-Miguel, X. (2004) Anfibios y reptiles. Pp. 375-390. In: A. J. García-Mendoza, M. de J. Ordóñez \& M. Briones-Salas (Eds.). Biodiversidad de Oaxaca. Instituto de Biología, UNAM · Fondo Oaxaqueño para la Conservación de la Naturaleza · World Wildlife Fund, D.F. [Mexico City].

Ceulemans, N. (2006) Jean Linden · Explorer, master of the orchid. Fonds Mercator, Brussels, 237 [+2] pp. [original ed. 2006, Jean Linden - Explorateur, père des orchidées. Fonds Mercator, Bruxelles, $237(+2)$ pp.].

Comas, J. (1967) El cráneo supuestamente atribuido a Moctezuma II. Estudios de Cultura Náhuatl, 7, 283-288.

Conant, R. (1965) Miscellaneous notes and comments on toads, lizards, and snakes from Mexico. American Museum Novitates, 2205, 1-38.

Cope, E. D. (1860). Catalogue of the Colubridae in the Museum of the Academy of Natural Sciences of Philadelphia, with notes and descriptions of new species. Part 2. Proceedings of the Academy of Natural Sciences of Philadelphia, 12(6), 241-266.

Cope, E. D. (1861) Contributions to the ophiology of Lower California, Mexico and Central America. Proceedings of the Academy of Natural Sciences of Philadelphia, 13(7), 292-306.

Cope, E. D. (1864) Contributions to the herpetology of tropical Amer- ica. Proceedings of the Academy of Natural Sciences of Philadelphia, 16(3), 166-181.

Cope, E. D. (1865) Third contribution to the herpetology of tropical America. Proceedings of the Academy of Natural Sciences of Philadelphia, 17(4), 185-198.

Cuvier, G. 1807. Sur les différentes espèces de crocodiles vivans et sur leurs caractères distinctifs. Annales du Muséum d'Histoire naturelle [Paris], 10, 8-66.

Davis, W. B. \& Smith, H. M. (1953) Snakes of the Mexican State of Morelos. Herpetologica, 8(4), 133-143.

Decaisne, J. (1847) Sur quelques plantes nouvelles ou peu connues, actuellement en fleurs dans les serres du Muséum. Revue Horticole (3e sér.), 1, 86-87.

Decaisne, J. (1873) Remarques sur les espèces du genre Eryngium, à feuilles parallélinerves. Bulletin de la Société Botanique de France, 20, 19-27.

Deppe, W. (1830) Preis-Verzeichnifs der Säugethiere, Vögel, Amphibien, Fische und Krebse, welche von den Herren Deppe und Schiede in Mexico gesammelt worden [...] sind. Published by author, Berlin, 3 pp. [reprinted 1863 with misleading title in Journal für Ornithologie, XI, 54-60].

Diagre, D. (2011) Les “plant-hunters" belges durant le règne de Léopold 1er (1831-1870): succès et paradoxe. Circumscribere, 9, 78-99.

Dubois, A. (1875) Descriptions de quelques oiseaux nouveaux. Bulletins de l'Académie royale des Sciences, des Lettres et des BeauxArts de Belgique (2me sér.), 40, 797-801.

Du Bus, B. (1845-1848) [incl. 1846 (Part II) and 1847b: Part III, 14 pp., plates 11-15]. Esquisses ornithologiques; descriptions et figures d'oiseaux nouveaux ou peu connus. Four parts in one volume. A. Vandale, Bruxelles, 50 pp., 20 plates.

Du Bus, B. (1847a) Note sur quelques espèces nouvelles d'oiseaux d'Amérique. Bulletins de l'Académie royale des Sciences, des Lettres et des Beaux-Arts de Belgique, 14 [2 $2^{\mathrm{e}}$ partie, Classe des Sciences № 8]: 101-108.

Du Bus, B. (1855) Note sur quelques espèces inédites d'oiseaux. Bulletins de l'Académie royale des Sciences, des Lettres et des Beaux-Arts de Belgique, 22 [ $1^{\mathrm{re}}$ partie, Classe des Sciences № 2]: $150-157$.

Du Buysson, F. (1878) L'orchidophile · Traité théorique et pratique sur la culture des orchidées. Auguste Goin, Paris, 536 pp.

Duellman, W. E. (2001) The hylid frogs of Middle America. Vol. 1. University of Kansas, Lawrence [Museum of Natural History Monograph 1], XVI + 694 pp. [SSAR reprint].

Dugès, A. (1896) Reptiles y batracios de los E. U. Mexicanos. La Naturaleza (seg. ser.), 2 [1891-1896], 479-485.

Duméril, A. H. (1856) Description des reptiles nouveaux ou imparfaitement connus de la collection du Muséum d'histoire naturelle et remarques sur la classification et les caractères des reptiles. Deuxième mémoire. Archives du Muséum d'Histoire naturelle, Paris, 8, 437-588.

Duméril, A. M. (1853) Prodrome de la classification des reptiles ophidiens. Mémoires de l'Académie des Sciences de l'Institut de France, XXIII: 399-536.

Duméril, A. M. \& Bibron, G. (1841) Erpétologie générale ou histoire naturelle complète des reptiles. Tome huitième. Roret, Paris, III $+792 \mathrm{pp}$. 
Duméril, A. M. \& Bibron, G. (1844) Erpétologie générale ou histoire naturelle complète des reptiles. Tome sixième. Roret, Paris, $\mathrm{XII}+609[+1] \mathrm{pp}$.

Duméril, A. M., Bibron, G. \& Duméril, A. H. (1854a) Erpétologie générale ou histoire naturelle complète des reptiles. Tome septième. Première partie. Roret, Paris, XVI +780 pp. [incl. Atlas, 24 pp. and 110 ("120") plates (I-XXXIX, XXXIXbis, XL-XLI, XLIbis, XLII-LXXIV, LXXVbis-LXXXIVbis, LXXXV-CVIII) encompassing amphibians and reptiles of vols 1 (1834) to 9 (1854)].

Duméril, A. M., Bibron, G. \& Duméril, A. H. (1854b) Erpétologie générale ou histoire naturelle complète des reptiles. Tome septième. Deuxième partie. Roret, Paris, XII + 756 pp. [781-1536].

Duméril, A. M., Bibron, G. \& Duméril, A. H. (1854c) Erpétologie générale ou histoire naturelle complète des reptiles. Tome neuvième. Roret, Paris, $\mathrm{XX}+440 \mathrm{pp}$

Duméril, A. M. \& Duméril, A. H. (1851) Catalogue méthodique de la collection des reptiles du Muséum d'Histoire naturelle de Paris. Gide et Baudry, Paris, IV + 224 pp.

Dunn, E. R. (1926) The salamanders of the family Plethodontidae. Smith College, Northampton MA, VIII + $441 \mathrm{pp}$.

Fischer, P. \& Crosse, H. (1888) Études sur les mollusques terrestres et fluviatiles du Mexique et du Guatemala (1880-1902). 10 ${ }^{\mathrm{e}}$ Livr. Pp. 129-176 [plates XLIII-XLVI]. In: M. Milne Edwards (Ed.). Mission scientifique au Mexique et dans l'Amérique Centrale. Recherches zoologiques. Septième Partie. Tome Second. Imprimerie Nationale, Paris.

Fischer, P. \& Crosse, H. (1890) Études sur les mollusques terrestres et fluviatiles du Mexique et du Guatemala (1880-1902). 11 ${ }^{\mathrm{e}}$ Livr. Pp. 177-256 [plates XLVII-XLVIII]. In: ibid.

Fischer, P. \& Crosse, H. (1893) Études sur les mollusques terrestres et fluviatiles du Mexique et du Guatemala (1880-1902). 14 Livr. Pp. 400-488 [plates LV-LVIII]. In: ibid.

Fitzinger, L. (1843) Systema Reptilium. Amblyglossae. Braumüller \& Seidel, Vindobonae [Vienna], $106+$ VI [+ 3] pp.

Flores-Villela, O., Smith, H. M. \& Chiszar, D. (2004) The history of herpetological exploration in Mexico. Bonner zoologische Beiträge, 52(3/4), 311-335.

Fournier, E. (1872) Mexicanarum Plantarum Pars Prima. Mexicanas plantas nuper collectoribus expeditionis scientificæ allatas [...]. Cryptogamia. In: J. Decaisne (Ed.). Mission scientifique au Mexique et dans l'Amérique Centrale (1870-1909). Recherches botaniques. Typograph.[ia] Reipubl.[icae], Paris, 166 pp.

Fournier, E. (1886). Mexicanarum Plantarum Pars Secunda [...]. Graminées. In: ibid. Imprimerie Nationale, Paris. XIX + 160 pp.

Ghiesbreght, A. (1839) [Escalade de l'Orizaba]. Le Courrier [Luxembourg], March 7.

Godínez-Ortega, J. L. (2008) Colectores de algas de México (17871954). Acta Botanica Mexicana, 85, 75-97.

Gray, A. (1884) Contributions to North American botany. Proceedings of the American Academy of Arts and Sciences, 19, 1-96.

Günther, A. (1872) Seventh account of new species of snakes in the collection of the British Museum. The Annals and Magazine of Natural History (4 ${ }^{\text {th }}$ ser.), 9 [49], 13-37.

Hellmayr, C. E. (1934) Catalogue of birds of the Americas and the adjacent islands. Part VII. Field Museum of Natural History (Zoological Series), 13 [VII]: VI + 1-531.
Hemsley, W. B. (1883) Orchideae. Pp. 197-308. In: F. D. Godman \& O. Salvin (Eds.). Biologia Centrali-Americana (1885-1902). Botany. Vol. III [1882-1886]. R. H. Porter, London.

Hemsley, W. B. (1887) [Appendix] A sketch of the history of the botanical exploration of Mexico and Central America. Pp. 117-137. In: F. D. Godman \& O. Salvin (Eds.). Biologia Centrali-Americana (1885-1902). Botany. Vol. IV [1886-1888]. Taylor \& Francis, London.

Hupé, H. (1857) Animaux nouveaux ou rares recueillls pendant l'expedition dans les parties centrales de l'Amérique du Sud $\mid . .$.$] .$ Mollusques. P. Bertrand, Paris, 403 pp.

Jackson, B. (1901) A list of the collectors whose plants are in the herbarium of the Royal Botanic Gardens, Kew, to 31st December 1899. Bulletin of Miscellaneous Information, 169, 1-79.

Jan, G. (1863) Elenco sistematico degli ofidi descritti e disegnati per l'iconografia generale. A. Lombardi, Milano, VII + 143 pp.

Jan, G. \& Sordelli, F. (1866) [1867]. Iconographie générale des ophidiens (1860-1881). 19 $9^{\text {ème }}$ livr. F. Sordelli · J. B. Baillière et Fils, Milan · Paris, 6 plates [published "Décembre 1866"].

Jaussaud, P. \& Brygoo, É.-R. (2004) Du jardin au Muséum en 516 biographies. Collection Archives 7. Muséum national d'Histoire naturelle, Paris, $632 \mathrm{pp}$.

Kofron, C. P. (1982) The identities of some dipsadine snakes: Dipsas elegans, D. ellipsifera and Leptognathus andrei. Copeia, 1982 (1), 46-51.

Kofron, C. P. (1990) Systematics of Neotropical gastropod-eating snakes: the dimidiata group of the genus Sibon, with comments on the nebulata group. Amphibia-Reptilia, 11(3), 207-223.

Kunth, C. S. (1817) Nova genera et species plantarum quas in peregrinatione ad plagam aequinoctialem orbis novi collegerunt Bonpland et Humboldt. Tomus secundus. Librairie GrecqueLatine-Allemande, Paris, 192 pp.

Lagasca, M. (1816) Genera et species plantarum, quae aut novae sunt. Typographia Regia, Madrid, VIII + $35[+2] \mathrm{pp}$

La Llave, P. de \& Lexarza, I. [J.]. (1825) Novorum vegetabilium descriptiones. Fasciculus II. M. Rivera, Mexico, 43 pp.

Lang, M. (1990) Annotated catalogue of the type-specimens from the herpetological collection of the Royal Belgian Institute of Natural Sciences, Brussels. Documents de Travail de l'Institut royal des Sciences naturelles de Belgique, 59, 1-36.

Lasègue, A. (1845) Musée botanique de M. Benjamin Delessert. Notices sur les collections de plantes et la bibliothèque qui le composent; contenant en outre des documents sur les principaux herbiers d'Europe et l'exposé des voyages entrepris dans l'intérêt de la botanique. Fortin, Masson et $\mathrm{C}^{\mathrm{ie}}$, Paris, $[10+] 588$ pp.

Laurent, R. (1949) Notes sur quelques reptiles appartenant à la collection de l'Institut royal des Sciences naturelles de Belgique. III. - Formes américaines. Bulletin de l'Institut royal des Sciences naturelles de Belgique, 25(9), 1-20.

Lemaire, C. [ed.]. (1845) Flore des serres et des jardins de l'Europe [...]. Vol. I. Louis Van Houtte, Gand, 310 pp.

Lesson, R. P. (1831) Traité d'ornithologie ou tableau méthodique des ordres, sous-ordres, familles, tribus, genres, sous-genres et races d'oiseaux. F. G. Lefrault, Paris, XXXII + 659 pp.

Liebmann, F. M. (1869) Chênes [sic] de l'Amérique tropical [...]. Leopold Voss, Leipzig, X +29 [+ 1, 'Corrigenda'] pp. [posthumously supplemented and edited by Anders Sandøe Ørsted]. 
Linden, J. \& Planchon, J. (1863) Plantae Columbianae. Troisiéme voyage de J. Linden, dans les parties intertropicales de l'Amérique [...] 1841 à 1845. Première Partie. Botanique. Tome 1 ${ }^{\mathrm{er}}$. M. Hayes, Bruxelles, LXXXVIII + 64 pp.

Linden, J. \& Planchon, J. (1867) Les explorations botaniques de la Colombie et en particulier le voyage de M. J. Linden de 1840 à 1844. La Belgique horticole, 17, 235-256.

Link, F. (1833) Hortus Regius Botanicus Berolinensis. Tomus II. G. Reimer, Berlin, IV + 376 pp.

Linnaeus, C. (1758) Systema naturae per regna tria naturae, secundum classes, ordines, genera, species, cum characteribus, differentiis, syonymis, locis. Editio decima, reformata. Tomus I. L. Salvi, Holmiae [Stockholm], IV + 823 [+ 1] pp.

Linnaeus, C. (1759) Systema naturae per regna tria naturae, secundum classes, ordines, genera, species, cum characteribus, differentiis, synonymis, locis. Vol. 2, Part II (editio decima, reformata). L. Salvi, Holmiae [Stockholm], 777 pp. [885-1661].

Linnaeus, C. (1766) Systema naturae per regna tria naturae, secundum classes, ordines, genera, species, cum characteribus, diferentiis, syonymis, locis. Editio duodecima, reformata. Tomus I. L. Salvi, Holmiae [Stockholm], $532 \mathrm{pp}$.

Lorence, D. H. (1999) A nomenclator of Mexican and Central American Rubiacea. Monographs in Systematic Botany from the Missouri Botanical Garden, 73, 1-177.

Macquart, J. (1850) Diptères exotiques nouveaux ou peu connus. 4. ${ }^{\mathrm{e}}$ Supplément [part]. Mémoires de la Société [Nationale] des Sciences, de l'Agriculture et des Arts de Lille, 1849, 309-479.

Macquart, J. (1851). Diptères exotiques nouveaux ou peu connus. Suite du 4. ${ }^{\text {e }}$ Supplément [end]. Mémoires de la Société Nationale des Sciences, de l'Agriculture et des Arts de Lille, 1850, 134294.

Martens, M. \& Galeotti, H. (1843) Enumeratio synoptica plantarum phanerogamicarum ab Henrico Galeotti in regionibus Mexicanis collectarum. Bulletins de l'Academie royale des Sciences et Belles-Lettres de Bruxelles, 10 [1 $1^{\mathrm{re}}$ partie] (3), 208-224.

Mata-Silva, V., Johnson, J. D., Wilson, L. D. \& García-Padilla, E. (2015) The herpetofauna of Oaxaca, Mexico: composition, physiographic distribution, and conservation status. Mesoamerican Herpetology, 2(1), 6-62.

Mather, C. M. \& Sites, J. W., Jr. (1985) Sceloporus variabilis Wiegmann Rose-bellied Lizard. Catalogue of American amphibians and reptiles, 373, 1-3.

McCranie, J. R. \& Köhler, G. (2004a) Laemanctus Wiegmann Casqueheaded Basilisks, Cutetes. Catalogue of American amphibians and reptiles, 794, 1-2.

McCranie, J. R. \& Köhler, G. (2004b) Laemanctus serratus Cope Serrate Casqueheaded Basilisk [...]. Catalogue of American amphibians and reptiles, 796, 1-5.

McVaugh, R. (1972) Botanical exploration in Nueva Galicia, Mexico, from 1790 to the present time. Contributions from the University of Michigan Herbarium, 9(3), 205-357.

Mocquard, F. (1908) Études sur les reptiles et les batraciens. 16 Livr. Pp. 861-932 [plates 69-74]. In: A. H. Duméril, M. Bocourt \& F. Mocquard (Eds.). Mission scientifique au Mexique et dans l'Amérique Centrale (1870-1909). Recherches zoologiques. Troisième partie. $1^{\text {re }}$ section [Reptiles]. Imprimerie Nationale, Paris.
Morren, E. [ed.]. (1857) Plantes nouvelles, introduites par M. J. Linden [...]. La Belgique horticole, 7, 196-199 [extract from Linden's 1857 sales brochure of plants].

Murray, G. (1904) Chronological account of the principal accessions to the botanical collections to the end of 1902. Pp. 85-128. In: E. R. Lankester (Ed.). The history of the collections contained in the Natural History departments of the British Museum. Vol. 1. Trustees of the British Museum (Natural History), London, XVII $+442 \mathrm{pp}$.

Naudin, C. (1851) Melastomacearum quæ in Musæo Parisiensi continentur [...]. Annales des Sciences Naturelles (3e sér., Botanique), $16,83-246$.

Neumann, L. (1843) Columnea Lindenii. Plate 21 (text). In: Herbier général de l'amateur (2 ${ }^{e}$ sér.). Vol. 3. H. Cousin, Paris.

Nyst, H. (1841) Notice sur deux coquilles mexicaines, appartenant aux genres Pupa et Helix. Bulletins de l'Académie royale des Sciences et Belles-Lettres de Bruxelles, 8 [1 ${ }^{\mathrm{re}}$ partie] (5), 343-345.

Ossenbach, C. (2007) History of orchids in Central America Part II: The New Republics-1821-1870. Selbyana, 28(2), 169-209.

Ossenbach, C. (2009) Orchids and orchidology in Central America: 500 years of history. Lankesteriana, 9(12), (II +) 1-268.

Papavero, N. (1971). Essays on the history of Neotropical dipterology, with special reference to collectors (1750-1905). Vol. I. Museu de Zoologia, Universidade de São Paulo, VII + 216 pp.

Papavero, N. \& Ibáñez-Bernal, S. (2001) Contributions to a history of Mexican dipterology. Part I. Entomologists and their works before the Biologia Centrali-Americana. Acta Zoológica Mexicana (n. s.), 84, 65-173.

Pérez-Higareda, G. \& Smith, H. M. (1991) Ofidiofauna de Veracruz. Análisis taxonómico y zoogeográfico. Instituto de Biología UNAM, Publicaciones Especiales 7, 122 pp.

Peters, W. (1864) [Ü]ber einige neue Säugethiere (Mormops, Macrotus, Vesperus, Molossus, Capromys), Amphibien (Platydactylus, Otocryptis, Euprepes, Ungalia, Dromicus, Tropidonotus, Xenodon, Hylodes) und Fische (Sillago, Sebastes, Channa, Myctophum, Carassius, Barbus, Capoëta, Poecilia, Saurenchelys, Leptocephalus). Monatsberichte der Königlichen Preuss. Akademie der Wissenschaften zu Berlin, 1864 (Juni), 381-399.

Pfeiffer, L. (1849) Description of twenty-nine new species of Helicina, from the collection of $\mathrm{H}$. Cuming, Esq. Proceedings of the Zoological Society of London, 1848, 119-125.

Pfeiffer, L. (1852) Catalogue of Phaneropneumona, or terrestrial operculated mollusca [...]. Trustees of the British Museum (Natural History), London, $324 \mathrm{pp}$.

Pfeiffer, L. (1856a-c) Uebersicht der Gattung Cylindrella [a]; Neue Mexicanische Landschnecken [b]; Diagnosen interessanter Novitäten [c]. Malakozoologische Blätter, 3, 209-229, 229-237, and 256-261.

Pfeiffer, L. (1857) Descriptions of nineteen new species of land-shells, from Mr. H. Cumming's collection, collected by M. Ghiesbreght at Chiapa, Mexico. Proceedings of the Zoological Society of London, 1856, 377-381.

Pfeiffer, L. (1866) Beschreibung neuer Landschnecken. Malakozoologische Blätter, 13, 76-91.

Poeppig, E. \& Endlicher, S. (1838) Nova genera ac species plantarum quas in regno Chilensi Peruviano et in Terra Amazonica. Vol. secundum. F. Hofmeister, Lipsiae [Leipzig], 74 pp., 100 plates. 
Possemiers, J. (1993a) Les relations Belgique-Mexique (1830-1864). Rêveries mexicaines en Belgique. Pp. 9-29. In: Les Belges et le Mexique [Dix contributions à l'histoire des relations BelgiqueMexique]. Avisos de Flandes 3. Presses Universitaires, Louvain [Leuven].

Possemiers, J. (1993b) Naturalistes belges au Mexique (1830-1840). Collectionneurs de plantes, de fleurs, de papillons et d'autres insectes. Pp. 31-35. In: ibid.

Reeve, L. A. (1856) Monograph of the genus Ampullaria. Conchologia Iconica: or illustrations of shells of molluscous animals. Vol. X. Lovell Reeve, London, 160 pp., 18 plates.

Reichenbach, H. G. (1856) Orchideae Ruizianae et Pavonianae Musaei Boissieriani. Bonplandia, 4(11), 210-217.

Renner, S. S. \& Hausner, G. (2005) Flora Neotropica Monograph 95. Siparunacea. Organization for Flora Neotropica · New York Botanical Garden, Bronx, $247 \mathrm{pp}$.

Richard, A. \& Galeotti, H. (1845) Orchidographie Mexicaine, D'après les échantillons, notes et dessins de MM. Galeotti, Linden, Funck, Ghiesbreght. Annales des Sciences naturelles ( $3^{e}$ sér., Botanique), 3, 15-33.

Richling, J. \& Glaubrecht, M. (2008) The types of Neotropical Helicinidae (Mollusca, Gastropoda, Neritopsina) in the malacological collection of the Museum für Naturkunde Berlin: an annotated catalogue, with emphasis on Cuban land snails. Zoosystematics and Evolution, 84(2), 265-310.

Rossman, D. A., Ford, N. B. \& Seigel, R. A. (1996) The garter snakes: evolution and ecology. University of Oklahoma Press, Norman, XX $+332 \mathrm{pp}$.

Roux-Estève, R. (1983) Les spécimens-types du genre Micrurus (Elapidae) conservés au Muséum national d'Histoire naturelle de Paris. Memórias do Instituto Butantan, 46 [1982], 79-94.

Rovirosa, J. (1889) Vida y trabajos del naturalista belga Augusto B. Ghiesbreght, explorador de México. La Naturaleza (seg. ser.), 1 [1887-1890], 211-217.

Rovirosa, J. N. (1893) Viaje a Teapa y á las sierras que concurren á la formación de su valle. Tipografía del Gobierno, San Juan Bautista [Villahermosa], $80 \mathrm{pp}$.

Rovito, S. M., Parra Olea, G., Recuero, E. \& Wake, D. B. (2015) Diversification and biogeographical history of Neotropical plethodontid salamanders. Zoological Journal of the Linnean Society, 175, 167-188.

Salvin, O. (1882) A catalogue of the collection of birds formed by the later Hugh Edwin Strickland. University Press, Cambridge [GB], $\mathrm{XVI}+652 \mathrm{pp}$.

Say, T. (1827-1829) Descriptions of some new terrestrial and fluviatile shells of North America. The Disseminator of Useful Knowledge, 1-2 [not seen, republished in 1840 at New Harmony, Indiana].

Sayre, G. (1975) Cryptogamae Exsiccatae-An annotated bibliography of Exsiccatae of Algae, Lichenes, Hepaticae, and Musci V. Unpublished Exsiccatae I. Collectors. Memoirs of the New York Botanical Garden, 19(3), 277-423.

Scheidweiler, M. J. F. (1842) Notice sur quelques nouveaux genres et espèces de plantes. Bulletins de l'Academie royale des Sciences et Belles-Lettres de Bruxelles, 9 [1 ${ }^{\text {re }}$ partie] (1), 19-26.

Schlegel, H. (1837) Essai sur la physionomie des serpens. 2 vols. Kips \& Stockum, La Haye, [7 +] 27 [II - XXVIII] + $251[+1]$ pp. and
$[6+] 606[+2]+\mathrm{XV}[+1] \mathrm{pp}$. Atlas $[2$ pp. +$]$ XXI plates +3 maps +2 tables $+1 \mathrm{p}$.

Schmidt, K. P. (1933) Preliminary account of the coral snakes of Central America and Mexico. Field Museum of Natural History (Zoological Series), 20(6), 29-40.

Schätti, B. \& Stutz, A. (2016) A short account of the snakes of Southern Oaxaca, Mexico. Published by authors, Oaxaca de Juárez, 40 pp.

Sclater, P. L. (1859) List of birds collected by M. A. Boucard in the State of Oaxaca, in South-western Mexico, with descriptions of new species. Proceedings of the Zoological Society of London, 1859 [III], 369-383.

Shaw, G. (1802) General zoology, or systematic natural history. Vol. III. Part II. Amphibia. G. Kearsley, London, VIII + pp. 313-615.

Silvestre, M. (2014) Ghiesbreght, Boniface Augustin Lucien dit Auguste. Pp. 142-150 and 432-435. In: Autour de Philippe Vandermaelen. Répertoire biographique des collaborateurs de l'Etablissement géographique de Bruxelles et de l'Ecole Normale. Inventaire raisonné des collections cartographiques Vandermaelen [...] VI. Bibliothèque royale de Belgique, Bruxelles.

Silvestre, M. (2016) Philippe Vandermaelen, Mercator de la jeune Belgique. Histoire de l'Etablissement géographique de Bruxelles et de son fondateur. Inventaire raisonné des collections cartographiques Vandermaelen [...] VII. Bibliothèque royale de Belgique, Bruxelles, 568 pp.

Smith, H. M. (1942a) The synonymy of the Garter Snakes (Thamnophis), with notes on Mexican and Central American species. Zoologica, 27(3-4), 97-123.

Smith, H. M. (1942b) A résumé of Mexican snakes of the genus Tantilla. Zoologica, 27(7), 33-42.

Smith, H. M. (1971) Distribution of the racer Coluber constrictor in Mexico. Journal of Herpetology, 5(3-4), 212-214.

Smith, H. M. \& Laufe, L. E. (1945) Mexican amphibians and reptiles in the Texas Cooperative Wildlife Collections. Transactions of the Kansas Academy of Science, 48(3), 325-354.

Smith, H. M. \& Taylor, E. H. (1945) An annotated checklist and key to the snakes of Mexico. United States National Museum Bulletin, 187, IV $+1-239$.

Smith, H. M. \& Taylor, E. H. (1950a) An annotated checklist and key to the reptiles of Mexico exclusive of the snakes. United States National Museum Bulletin, 199, V + 1-253.

Smith, H. M. \& Taylor, E. H. (1950b) Type localities of Mexican reptiles and amphibians. The University of Kansas Science Bulletin, 33 [II] (8), 313-380.

Solano-Zavaleta, I., García-Vázquez, U. O. \& Mendoza-Hernández, A. A. (2009) Notas sobre la distribución geográfica de las salamandras Pseudoeurycea gadovii y Pseudoeurycea melanomolga (Caudata: Plethodontidae). Revista Mexicana de Biodiversidad, 80(2), 575-577.

Soto Arenas, M., Salazar, G. A. \& Rojas, A. (1993) Nomenclatural changes in Rhynchostele, Mesoglossum, and Lemboglossum (Orchidaceae, Oncidiinae). Orquídea [Mexico City], 13(1-2), 145152.

Standley, P. C. \& Steyermark, J. A. (1943) Studies of Central American plants-III. Field Museum of Natural History (Botanical Series), 23(1) [524], 1-28.

Stephens, J. (1841) Incidents of travel in Central America, Chiapas, 
and Yucatan. Vol. II. Harper \& Brothers, New York, VII +470 [“474"] pp.

Stull, O. G. (1940) Variations and relationships in the snakes of the genus Pituophis. United States National Museum Bulletin, 175, VI + 1-225.

Sumichrast, F. (1880) Contribution à l'histoire naturelle du Mexique I. Notes sur une collection de reptiles et de batraciens de la partie occidentale de l'Isthme de Tehuantepec. Bulletin de la Société Zoologique de France, 5, 162-190.

Swartz, O. (1797) Flora Indiae Occidentalis [...]. Tomus I. J. J. Palm, Erlangae, VIII + 640 pp.

Swartz, O. (1800) Orchidernes slágter och arter upstállde. Kongl. Vetenskaps Academiens Nya Handlingar, 21 (July-September): 202-254.

Thireau, M. (1986) Catalogue des types d'urodèles du Muséum national d'Histoire naturelle Revue critique. Ministère de l'Éducation nationale, Paris, $97 \mathrm{pp}$.

Thompson, F. G. (2008) An annotated checklist and bibliography of the land and freshwater snails of Mexico and Central America. Available at: http://www.flmnh.ufl.edu/malacology/mexico-central_america_snail_checklist/index.htm (accessed on December 2016).

Townsend, J. K. (1837) Description of twelve new species of birds, chiefly from the vicinity of the Colombia River. Journal of the Academy of Natural Sciences of Philadelphia, 7, 187-194.

Tulasne, L.-R. (1855) Diagnoses nonnullas e Monimiacearum recensione tentata excerptas. Annales des Sciences Naturelles [quatr. sér.] (Botanique), 3(1), 29-46.

Van Rossem, A. (1939) Notes on avian types [unpublished manuscript (407 pp.) hold in the Alexander Wetmore collection incorporated into the Smithsonian Institution Libraries].

Van Rossem, A. (1940) Du Bus' type of the Collared Towhee, Pipilo torquatus. The Wilson Bulletin, 52(3), 173-174.

Van Rossem, A. (1942) Du Bus' types of Cyanocorax unicolor and Sylvia taeniata. The Wilson Bulletin, 53(3), 212-213.

Vieillot, L. P. (1807) Histoire naturelle des oiseaux de l'Amérique Septentrionale. Tome 1. Desray, Paris, IV + 90 pp.

Von Martens, E. (1890) Land and Freshwater Mollusca (1890-1901). Pp. 1-40. In: F. D. Godman \& O. Salvin (Eds.). Biologia Centrali-

\section{APPENDIX}

Northern Mesoamerican bird species deposited in the IRSNB and collected, or potentially gathered, by Auguste Ghiesbreght. Indicated are valid name, protonym or denomination and origin as reported in description (Bonaparte, 1850, 1853; Du Bus, 1845-1855; Dubois, 1875), accession number(s), and status (remarks incl. register entries). An asterisk precedes species or individuals lacking collecting data (see Sources and Material regarding incomplete record). Aphelocoma unicolor (Cyanocorax u. Du Bus, 1847a: "Mexique"; Du Bus 1848: "Tabasco"), 3034 (holotype, see Discussion incl. Nota 17); Buteogallus anthracinus (Deppe, 1830) (Morphnus mexicanus Du Bus, 1847a: "province de Tabasco [...] et le Guatimala"), 3031 ("type, Tabasco, Voyage Ghiesbreght") and 4724 ("Tabasco", juv. skin, "Ghiesbrecht, don.”); *Cardinalis cardinalis carneus (Lesson, 1842), 7418 ("Mex-
Americana (1885-1902). Zoologia. Mollusca. Taylor \& Francis, London.

Von Martens, E. (1893) Land and Freshwater Mollusca (1890-1901). Pp. 177-248. In: ibid.

Wallach, V., Williams, K. L. \& Boundy, J. (2014) Snakes of the world. A catalogue of living and extinct species. CRC Press, Boca Raton London New York, XXVIII + 1209 pp.

Waterfall, U. T. (1967) Physalis in Mexico, Central America and the West Indies. Rhodora, 69(777), 82-120.

Wellman, J. (1963) A revision of snakes of the genus Conophis (family Colubridae, from Middle America). University of Kansas Publications, Museum of Natural History, 15(6), 251-295.

Werner, F. (1909) Neue oder seltnere Reptilien des Musée Royal d'Histoire naturelle de Belgique in Brüssel. Zoologische Jahrbücher (Systematik, Geographie und Biologie), 28(3), 263288.

Wiedemann, C. R. W. (1828) Aussereuropäische zweiflügelige Insekten. Als Fortsetzung des Meigenschen Werkes. Erster Theil. Schulz, Hamm, XXXII+ 608 pp.

Wiegmann, A. F. (1828) Beyträge zur Amphibienkunde. Isis [Oken], 21 (4): cols 364-383.

Wiegmann, A. F. (1834) Herpetologia Mexicana, seu descriptio amphibiorum Novae Hispaniae [...]. Pars Prima. Saurorum species amplectens, adiecto systematis saurorum prodromo [...]. C. G. Lüderitz, Berlin, 54 pp.

Wilson, L. D. (1966) The range of the Rio Grande Racer in México and the status of Coluber oaxaca (Jan). Journal of Herpetology, 22(1), 42-47.

Wilson, L. D. (1988) Tantilla deppei (Bocourt). Catalogue of American amphibians and reptiles, 452.1.

Wilson, L. D. (1978) Coluber constrictor Linnaeus Racer. Catalogue of American amphibians and reptiles, 218, 1-4.

Wilson, L. D. \& Mata-Silva, V. (2015). A checklist and key to the snakes of the Tantilla clade (Squamata: Colubridae), with comments on distribution and conservation. Mesoamerican Herpetology, 2(4), 418-498.

Wilson, L. D. \& Meyer, J. R. (1981) Systematics of the calamarina group of the colubrid snake genus Tantilla. Contributions in Biology and Geology, Milwaukee Public Museum, 42, 1-25.

ique", Õ, achat Du Bus 1876); Caryothraustes poliogaster (Pitylus p. Du Bus, 1847a: "Guatimala"), *3042 (holotype, achat Du Bus 1876) and 7417 ("Mexique, Tabasco, Ghiesbrecht, don."); *Chlorophonia occipitalis (Euphonia o. Du Bus, 1847b: "Mexique"), 3026 (holotype, description based on various unidentified specimens); *Chlorospingus flavopectus ophthalmicus (Arremon o. Du Bus, 1847a: "Mexique", number(s), status, and collector(s) unknown); Cyanocorax luxuosus (Lesson, 1839) (same binomen in Du Bus 1848: "Jalapa" [Xalapa]), 5258 ("Mexique, Ghiesbrecht, don."); Cyanocorax yucantanicus (Cyanocitta yucantanica Dubois, 1875: "Yucatan" (Mexique), Ghiesbreght), 3091 (ad. holotype) and 3092-93 (juv. paratypes); *Cyanolyca nanus (Cyanocorax n. Du Bus, 1847a: "Mexique"), 3033 (holotype); *Granatellus venustus Bonaparte, 1850 ("Mexico"), 3028 (holotype); Icterus auratus Bonaparte, 1850 ("Yucatan"), 3051 (holotype, "Voyage Ghiesbreght"); *Peucedramus taeniatus (Sylvia taeniata Du Bus, 
1847a: "Mexique"), 3039 ( $\lesssim$ holotype, see Discussion regarding type locality); *Pipilo cf. torquatus Du Bus, 1847a ("Mexique"), 3043 (ठ઼ holotype, see Sources and Material); *Piranga erythrocephala (Swainson, 1827) (Pyranga cucullata Du Bus, 1847a: "Mexique”), 3040 (holotype, registered from "Talca [?= Tlalca, Veracruz], Mexique"), 3041 (paratype); Pseudastur albicollis ghiesbreghti (Buteo ghiesbreghti Du Bus, 1845: "Hacienda de Mirador", Veracruz), 3014-15 (incl. holotype, "Mexique, Voyage Ghiesbreght", see Nota 15); *Saltator coerulescens grandis (Deppe, 1830) (S. icteropyga Du Bus, 1847b: "Mexique"), 3025 (holotype, achat Du Bus 1876); *Spinus pinus macropterus (C.[arduelis] macroptera Bonaparte, 1850: "Guatimala, Mexico"), 3027 (holotype, "Mexique", achat Du Bus 1876); Tangara larvata (Calliste larvata Du Bus, 1846: "province de Tabasco [...] Ghiesbreght [...] envoyée [...] en 1841”), 3020-21 (holotype and paratype); Trogon collaris Vieillot, 1817 (T. xalapensis Du Bus, 1845: nr. "Xalapa", coll. 1838, Ghiesbreght), 3016 (ad. §̊ syntype, see Discussion); Turdus rufitorques Hartlaub, 1844 (same binomen in Du Bus 1848: "province de Tabasco [...] Ghiesbreght [...] envoyés [...] en 1841”), 7581 (§), $7581 \beta$ (ㅇ, skin); *Vireolanius melitophrys Bonaparte, 1850 ("ex Mexic" [sic]), 3029 (holotype); *Zonotrichia leucophrys (Forster, 1772) (Spizella maxima Bonaparte, 1853: "Mexicain”), 3060 (holotype).

\section{Notae}

Nota 1. José Ramírez, son of the great intellectual Ignacio "El Nigromante", head of the natural history section in the Instituto Médico Nacional, and co-founder of the Sociedad Mexicana de Historia Natural, translated Jean Jules Linden's narration of the years with Nicolas Funck and Ghiesbreght in Mexico that appeared in an English weekly at the end of June 1879 (The Garden No. 397). This short report originally published in the introduction to the Plantae Columbianae (Linden \& Planchon, 1863) seems to be the only authentic account of a member of the Belgian Mexico expedition (1838-1840) available to Rovirosa (1889). A slightly different French version was released in another horticultural journal (Linden \& Planchon 1867).

Nota 2. Ghiesbreght was born on March 10, 1812 (Silvestre, 2014), and not in 1810 as found throughout the pertinent literature (e.g., Rovirosa, 1889; Anonymous, 1893b; Papavero \& Ibáñez-Bernal, 2001). A few irrelevant details remain vague or controversial, for instance the circumstances of the party's advent in Mexico (see Life in Mexico). According to Possemiers (1993a), the royal envoy left Havana for Veracruz before the naturalists ("A la fin de janvier [...] de Norman partit pour Veracruz") but Linden's (in Linden \& Planchon, 1863: XLVIII) words implicitly say that they reached Mexico City in company of the Belgian diplomatic mission headed by Baron de Norman. Ceulemans (2006) dates the latter's arrival in the capital at the "end of January 1838" where he "met up with" the expedition members "a few days later".

Nota 3. The reputed 1840 crossing of Yucatán or "entering also northern Guatemala" (e.g., Papavero, 1971: 177) do not quite correspond to facts (see Nota 6). Various texts hawk existing misperceptions or erroneous ideas, and a number of authors do not quote, or ignore, original references. Ossenbach (2009), for instance, credits
Hemsley (1887) as authority for the localities visited during the 1840 traverse of Chiapas and Tabasco.

Nota 4. Ghiesbreght's Mexican herbarium comprising some 1200 specimens is in Paris (Sayre, 1975). A total of 503 digitalised items (proper collector's matches) gathered in the early 1840's and encompassing a good number of types are accessible at https:// science.mnhn.fr/institution/mnhn/collection/p/item/list?full_ text=Ghiesbreght (last visited February 25, 2017). Out of these, 372 show partly vague locality data (e.g., "Mexico" or "Mexique") and roughly two thirds (242 or 65\%) bear "Oaxaca" labels (see last chapter, Fig. 2). In reality, these plants originate from the hinterland of Acapulco, Michoacán, larger places in the central sector between the Pacific versant and the Gulf lowlands (e.g., vic. Iguala, Morelia, "Vera Cruz"), and north along the Sierra Madre Oriental into Hidalgo and to Tlacolula in Veracruz (Fig. 1). An undetermined orchid of the genus Oncidium Swartz, 1800 from "Honduras" (MNHN-P 430313, no date, ABG 396) certainly is from Mexico.

Nota 5. According to the report on the 1837-1840 collections elaborated by Linden and delivered at the beginning of 1841 (Silvestre, 2014), the shipments included lower vertebrates ("des reptiles en peau et dans l'alcool [...], ainsi qu'une collection de poissons préparés sur planchettes" [...], une peau de lézard, un caïman"), and a letter by Bernard Amé Léonard Du Bus de Gisignies (see Nota 16) dated December 1849 mentions a few jars with reptiles ("quelques bocaux de reptiles"). Ceulemans (2006) quotes an unspecified document issued in Ghent (Gand) on May 26, 1841 and kept in the Archives Générales du Royaume recording "a tiger, several monkeys, etc. brought back from Mexico by Ghysbreght [sic] and his companions." Information in van Rossem (1939) does not help to identify the collector of, for instance, the male paratype of Aphelocoma unicolor Du Bus from "San Pedro". Accession numbers used in this manuscript or by Werner (1909) and Laurent (1949) derive from an older catalogue and are different from those in the today valid IRSNB registers.

Nota 6. It is unclear whether and how deep Ghiesbreght and Funck entered the Yucatán Peninsula during Linden's convalescence, but the alleged exploration of the entire area ("toute la péninsule du Yucatan", Linden \& Planchon 1863) is certainly an exaggeration. Panicum lindeni Fournier, 1886 ("In sylvis Tiap (Yucatan), julio", an unclear indication) and grasses (coll. Linden) from "Campeche" were all obtained in July 1839 (e.g., Fournier, 1886: 44, 46, 50), and "Tabasco" specimens in October (1.c.: 40, "in lagunis prope Tabasco").

Nota 7. In August 1840, the conveyance left "Frontera (Tabasco)" near the mouth of the Usumacinta where Belgium had opened a consular agency (Possemiers 1993a-b). This is the town of Frontera mentioned by Rovirosa (1889: 215, “[ ...] condujo [...] á la Hermita, para bajar por los ríos Teapa y Grijalva á Frontera") in context with the overturned sailer Brillante de Liverpool off the coast of Tabasco in 1856 (see Sources and Material regarding year). After fifteen years overseas, Ghiesbreght finally arrived safe in Antwerp with the rescued collections.

Nota 8. In those days, the whole region was in turmoil and Linden's description refers to the northern part of the disintegrating Federal Republic of Central America with the capital San Salvador once extending from Costa Rica to extreme SE Chiapas (Soconusco). 
The latter is comprised of the region south of the watershed of the Sierra Madre of Chiapas and east of Mapastepec (Acacoyagua and Acapetahua Mun.) into San Marcos Department in limitrophe SW Guatemala. At the moment of the travel narrated by Linden, the Soconusco and the western highland region of Guatemala had established the ephemeral State of Los Altos with the capital Quetzaltenango, an independent member of the civil war-stricken federation. The Soconusco remained autonomous and neutral prior to its annexation by Mexico in 1842 .

Nota 9. In the 1850's, Gustave Keymolen was director of a mine and lived in Morelia, and Jean run, for instance, a flour mill near Zinapécuaro northeast of the capital (Possemiers, 1993a). The year of collecting ("1842" and "1844") of various plants from Michoacán (Arúmbaro, Morelia, ABG series) possibly including MNHNP 410738 ("Tuxpan", n²67a) may be erroneous, or of different provenance (see The "Oaxaca" Issue for a case of exchange or gift among collectors). Both Colima specimens were obtained in the lowlands near the capital ("environs de Colima dans les plaines") and not on the Volcán de Colima (3820 m asl) in adjacent Jalisco (see Sources and Material). The year ("1842") on the printed Paris labels is corrected with ink to 1845 . A pencil note in a different handwriting at the lower margin of the inspection report elaborated by Louis Neumann on behalf of the director, Adolphe Brongniart, and loosely enclosed to the 1874 in-house botanical catalogue says that orchids from northern Colima ("au nord de Colima", ABG) had arrived on August 19, 1847.

Nota 10. Twelve amphibians and just as many reptiles from unspecified places in "Mexique" (ABG) registered in May 1844 and April 1854 are not addressed in this study because they most probably do not originate from Oaxaca. The first lot consists of three lizard species, at least two of which not present in the 1842 and 1845 series (Table 1), namely "Cyclura [Ctenosaura] acanthura Gray" (Shaw, 1802) and "Gerrhonotus Lichenigerus Wagler", i.e., Barisia imbricata (Wiegmann, 1828) quoted in Duméril \& Duméril (1851). The larger 1854 cargo encompasses a "Bufo americanus", ten dried "Axolotl" in bad shape, seven lizards (incl. "Cnemidophorus sex-lineatus" and "Gerrhonotus imbricatus") among which five "Tropidolepis" belonging to four different species, and three taxonomically relevant vouchers. Entry n 10 ("Bolitoglossa spec. ?", MNHN-RA 6396) is the holotype of the False Brook Salamander Spelerpes sulcatum Brocchi, 1883, a junior synonym of S. cephalicus Cope, 1865 (Thireau, 1986, see Nota 20), the type species of Aquiloeurycea Rovito et al. (2015). The remaining name-bearers are MNHN-RA 0054 (lectotype of Homalocranion [Tantilla] deppii Bocourt, 1883: [579] 584, Pl. 36.11) and MNHN-RA 7321, a paralectotype of Tropidonotus mesomelanus Jan, 1863 ("dal Messico", lectotype design. Smith 1942a), i.e., Thamnophis melanogaster (Peters, 1864). The spelling of the former taxon's specific epithet (“deppei") as found in, for instance, Smith (1942b), Davis \& Smith (1953: restriction of type locality), Smith \& Taylor (1945), Wilson \& Meyer (1981: designation of "lectoholotype", ad. §), Wilson (1988: ibid.), or Wilson \& MataSilva (2015: "holotype") is incorrect.

Nota 11. Tomodon lineatus Duméril, Bibron \& Duméril was described upon at least two specimens of the MNHN-RA 3738-40 series. "Little is known about the type specimen [n 3738 , lectotype], and nothing, concerning its collector or the locality at which it was col- lected" (Wellman 1963). According to Bocourt (1876: 407), one individual is without indication of the donator ("l'un des types ne porte pas de nom de donataire") and two (one from "Schlumberger") are from Oaxaca de Juárez (Table 1), but MNHN-RA 3738-39 were later reported from "Mexique" (Bocourt, 1886). Two additional snakes from "Mexique" exchanged with Henri Dieudonné Schlumberger from Guebwiller (Haut-Rhin, Alsace) in March 1859 [sic] found in the handwritten 1864 catalogue of herpetological holdings are Leptophis mexicanus Duméril, Bibron \& Duméril, 1854 (MNHN-RA 3454) and Micrurus diastema (Duméril, Bibron \& Duméril, 1854) MNHN-RA 3919. According to Roux-Estève (1983), however, the coral snake is MNHN-RA 7656, the supposed "Colima" (or "clearly a west Mexican") specimen erroneously selected as lectotype of M. diastema (Schmidt, 1933: "No. 4620"). Hemsley (1887) notes that material with this provenance ("Schlumberger") was obtained by "Frederick Mueller [...] who went to Mexico in 1853, at the cost of Mr. Schlumberger of Mulhouse", and was supposedly "murdered and concealed, as he disappeared and was never heard of afterwards." Algae (Godínez-Ortega, 2008) and plants collected by F. Müller (or Mueller) are from Veracruz (see Ossenbach, 2009: 90). Fournier (1886) described the grass Andropogon schlumbergeri on the basis of material received from Müller (type locality "Orizaba"). Apart from four inconclusive place names ("Rimon [sic] de la Cartenueva", "Rinion [Riñon] de la Caronera", "Sierra de Camila", and "Camino del Aserradero"), most specimens (coll. Müller) mentioned in, for example, Fournier (1872: incl. Aserradero de Santa Cruz, Barranca de Consoquitla, Barranca dos Puentes, "Escumela" [Escamela], Ingenio, Sierra de Uluapa, Rio Blanco) are from Veracruz; "San Juan del Rio" may correspond to San Juan de los Ríos in SW Puebla, and not the town of the same name in Querétaro; "Barranca de San Francisco" is the denomination of various canyons in Puebla.

Nota 12. McCranie \& Köhler (2004a-b) mapped Laemanctus serratus for "central Oaxaca" on the basis of "two" unspecified "nineteenth-century records from the Pacific versant" (1.c. a). All indications of this species from Oaxaca (e.g., Bocourt, 1874: 116, "recueilli à Oaxaca"; Mata-Silva et al., 2015: Table 4) ultimately rely upon MNHN-RA 2094. The putatively second collecting site, viz. "Oaxaca: Tlacolula" (Smith \& Laufe, 1945), is no more than a vague interpretation of the capital's outskirts as reported by Duméril (1856: 512) combined with a literature record from Veracruz (Dugès 1896: incl. 'Tlacolula', see Nota 21) that soon converted into ostensibly reliable locality data (e.g., Smith \& Taylor 1950a).

Nota 13. Rhinechis mexicanus Duméril, 1853 is a nomen nudum. Stull (1940) or Smith \& Taylor (1945) mention a single "type" of Pituophis mexicanus Duméril, Bibron \& Duméril, 1854. Ever since the generic revision, the taxon has been considered a junior synonym of Coluber sayi Schlegel, 1837 (e.g., Wallach et al., 2014), a subspecies of $P$. catenifer (Blainville, 1835) according to the latter authors (see Bryson et al., 2011). The description of $P$. mexicanus avers usually four but sometimes just two prefrontals ("Ordinairement, $[\ldots]$ quatre pré-frontales [...] mais parfois on n'en voit que deux"). Two scales is typical of the endemic northern Mexican pinesnake species introduced under the subsequent genus (Elaphis auct.) within the same fascicle, viz. P. deppei (holotype "du Mexique" in "Musée de Leyde", Duméril et al. 1854a; type locality 
restricted to San Juan Teotihuacán, México State, Smith \& Taylor, 1950b). The syntype of $P$. mexicanus illustrated in Duméril et al. (1854a: P1. 62, "Anasime méxicain") shows two prefrontal (typical of deppei) and three scales (incl. incompletely divided left shield) are found in MNHN-RA 3188.

Nota 14. Kew Royal Gardens and the botanical department of the then British Museum (Natural History) purchased several hundred ABG specimens between 1868 and 1873 (Jackson, 1901; Murray, 1904, see Fig. 2). The original series of Portlandia (Coutaportla) ghiesbreghtiana Baillon, 1879 (MNHN-P 2273491-94) collected in April 1842 along the border of a ravine near Hacienda Huixastla ("en avril, près de l'hacienda de Huijastla, au bord des ravins", 1.c.) and placed in "Oaxaca" (ABG, coll. "1842-43") by Lorence (1999), for instance, is from a hamlet in Hidalgo’s Metztitlán Municipality (Fig. 1), and not Huixastla in Morelos (Tlaquiltenango Mun.) such as certain plants from that state bearing "Oaxaca" labels (see Nota 4 and last chapter incl. Nota 21). Supposedly new botanical species based on MNHN material from "Oaxaca" (ABG, coll. "1842") were described until the second half of the last century, for example the groundcherry Physalis constricta Waterfall, 1967 (holotype MNHN-P 387526, type locality “Oaxaca”, perhaps syn. P. campanula Standley \& Steyermark, 1943). Early intensive sampling by Ghiesbreght is documented for the Teapa region in Tabasco including NW Chiapas as exemplified by a Flying Fish or Goldfish Plant (Neumann 1843: "Columnea Lindenii”) and Heliconia aurantiaca (Lemaire 1845: 240, unnumb. pl., Aphelandra aurantiaca [Scheidweiler, 1842] "Lindley") introduced into European horticulture in 1841. Also, the restricted type localities of the land snail Eucalodium d. decollatum (Nyst, 1841) from "Tabasco" (ABG) and its junior synonym Cylindrella ghiesbreghti Pfeiffer, 1857 are situated close to Teapa (identical limestone site, Thompson 2008: as "C. gheisbreghti [sic] Pfeiffer, 1856"; type loc. Chiapa de Corzo). Numerous terrestrial gastropod taxa including the original series of about twenty-five nominal species collected by Ghiesbreght and described in Pfeiffer $(1856 a-c, 1857,1866)$ or Ampullaria ghiesbreghtii Reeve, 1856 (coll. "Ghiesbrecht" [sic], Mus. Cuming [BMNH], "Chiapes"), a junior synonym of Pomacea flagellata livescens (Reeve, 1856), hail from Chiapas. Further patronyms are Drymaeus ghiesbreghti (Pfeiffer, 1866), Euglandina ghiesbreghti (Pfeiffer, 1856b), Helicina ghiesbreghti Pfeiffer, 1857, and Lysinoe ghiesbreghtii (Nyst, 1841). Out of the six mentioned valid taxa, only $D$. ghiesbreghti is reported from Oaxaca (Tlacolula, von Martens, 1893: 209, coll. H. Höge) according to Thompson (2008). The type series of the congener D. chiapasensis (Pfeiffer, 1866) was obtained by Ghiesbreght at Cerro Manzanilla (Mt., "Cumbre de la Manzanilla") in Villaflores Municipality, Chiapas, after 1854. The provenance ("Colombia", ABG coll. "1842") of a syntype of Helix boussingaultii Hupé, 1857 (MNHNIM 2000.28025) is a mix-up of the country and/or the collector. The horsefly Chrysops geminatus Wiedemann, 1828 and type material of six Mexican diptera species received from "Ghisbrecht" [sic] (MNHN-E specimens), viz. the asilid Mallophora fulviventris Macquart, 1850 and tachinid Mochlosoma mexicanum (Macquart, 1851) as well as four junior synonyms of the former and three additional taxa (fide Papavero \& Ibáñez-Bernal, 2001), are all from unspecified localities ("Du Mexique").

Nota 15. Only the holotype of Buteo ghiesbreghti Du Bus (IRSNB
3014) from El Mirador near Totutla (“dans les environs de l'Hacienda de Mirador, à quelques lieues de Vera-Cruz") was obtained by the name-giving provider ("est le seul que M. Ghiesbreght ait pu rencontrer", Du Bus, 1845). A female stored in an unspecified institution and collected in March 1845 at Playa Vicente between Oaxaca and Veracruz ("tuée à Playa-Vicente, entre Oaxaca et Vera-Cruz (Mexique), en mars 1845") was possibly shot by Auguste Sallé who gathered, for instance, gastropods at this locality (e.g., Fischer \& Crosse, 1888: 131, von Martens, 1890: 7). The date, however, is doubtful in view of its publication that same year. A registered "cotype" of B. ghiesbreghti (IRSNB 3015) was acquired in August 1856 (see Silvestre, 2014: 149, note 823 ) and, consequently, cannot be part of the type series. It is noteworthy that in the decade to follow, Adolphe Boucard (via A. Sallé) procured various bird species at Playa Vicente, "a rancheria consisting of a group of cabins of bamboo, situated on the confines of the three States of Vera Cruz, Oaxaca, and Tehuantepec on the borders of the Rio Tesechoacan [Río Playa Vicente, a tributary of the Papaloapan] at the foot of the mountains of Oaxaca in the hot country (tierra caliente)" (Sclater, 1859, see Nota 16).

Nota 16. The holotype of Cyanoloxia [cyanoides] concreta Du Bus (IRSNB 3064) from "Playa-Vicente, au Mexique" (collector unknown, see Nota 15) and numerous other bird taxa belonging to the private collection of the first IRSNB director and curator until 1869, Baron Du Bus de Gisignies, were formally incorporated into the museum's holdings in 1876 ("Achat coll. Du Bus 4. IV. 1876"). A much higher number (99) of formerly unpublished avian species (ABG) in Du Bus (1845-1848) than listed herein (Appendix) given by Silvestre (2014: "Des oiseaux recueillis par Ghiesbreght, du Bus identifia, décrivit et publia nonante-neuf espèces inédites dans ses Esquisses ornithologiques") relies on a letter of the director dated November 9, 1849 addressed to the Minister of the Interior (1.c.: note 810).

Nota 17. Santiago Tepitongo is approximately 75 kilometres eastnortheast of Oaxaca de Juárez in the Zempoaltepec Range of Totontepec Villa de Morelos Municipality. The identity of San Pedro, a frequent place name, remains inconclusive. It is stated that "S. Pedro" is at high altitude near Oaxaca de Juárez ("près de Oaxaca, en terre froide", Du Bus 1848) whereas Santiago Tepitongo at about $1600 \mathrm{~m}$ above sea level is considered to be situated in the temperate zone ("en terre tempérée"). For this reason, we are close to convinced that the male IRSNB paratype of Aphelocoma unicolor and the Euphonia elegantissima couple were obtained either above Villa de Etla (ca. $1675 \mathrm{~m}$ asl), a town formerly called San Pedro at the base of Cerro San Felipe (C. Peña de S. F.) attaining elevations higher than $3000 \mathrm{~m}$, or near San Pedro Nolasco (e.g., Fournier, 1886: coll. Galeotti, July-October), viz. in the Santiago Xiacuí area above $2000 \mathrm{~m}$.

Nota 18. Smith \& Taylor (1945) qualify reports of "Coluber oaxaca" from "Tehuantepec" in SE Oaxaca by Sumichrast (1880) as "perhaps" doubtful. This binomen does not appear in the quoted reference. Rather, "Coluber sp. nov. ?" from the vicinity of San Pedro Tapanatepec ("près de Tapana") and "Coluber (indéterminé)" obtained in the Oaxacan Isthmus ("partie occidentale de l'Isthme de Tehuantepec", 1.c.) are enumerated. Both citations most probably rely on a colubrid different from the Oaxaca Racer or any other snake taxon discussed in our context (in prep.). 
Nota 19. References for distribution records from the Cofre de Perote Range and Huatusco-Xalapa sector except Pseudoeurycea gadovii (see above) are as follows: Smilisca baudinii (fide Duellman, 2001: Fig. 287), Laemanctus serratus (fide McCranie \& Köhler, 2004b: Map), Sceloporus grammicus microlepidotus (Boulenger 1885: “Jalapa"), S. variabilis (fide Mather \& Sites, 1985: Map), Coluber constrictor oaxaca (Wilson, 1966: "El Chico, 7 miles SSE Jalapa"), Conophis lineatus (Pérez-Higareda \& Smith, 1991: "N Huatusco"), and Sibon dimidiatus (1.c.: "Xalapa"). Within Veracruz, Pituophis catenifer is only recorded from the northernmost portion (Bryson et al., 2011: Fig. 2) and P. deppei (see Nota 13) is restricted to the described highland area ("Altas elevaciones del oeste de Veracruz, cerca de los límites con Puebla”, Pérez-Higareda \& Smith 1991). For the sake of completeness, we add that both Ghiesbreght snakes received in 1854 with the origin "Mexico" (see Nota 10) are absent from Veracruz and Puebla. The closest known populations of Thamnophis m. melanogaster ("confined to the Valley of Mexico", ranging north to Querétaro, Rossman et al., 1996: Map 14) occur in SE México State (Estado de México). Tantilla deppii is endemic to elevations above $1500 \mathrm{~m}$ asl "on the Pacific versant in northern Morelos, northern Guerrero, and northwestern Oaxaca" (Wilson \& Mata-Silva, 2015), and the restriction of the type locality to Huitzilac in Morelos (Davis \& Smith, 1953) makes sense (see below in main text regarding Ghiesbreght plants from this state).

Nota 20. Ghiesbreght's disclosed correspondence almost entirely relates to plants or gives lengthy explications for the appropriate transport of living orchids. He hardly ever talks about zoological aspects, and if so in purely general terms. By all means, we did not come across a mention of a vertebrate or, for instance, any specific animal names at all (see beginning of chapter and elsewhere). Natural history items from, literally, all fields announced to Brongniart in April 1852 constitute a rare indication of faunistic material, in this case a prospect shipment to the Paris Museum ("[...] mes envois successifs que je ferai pour toutes les branches de l'histoire naturelle"). Vertebrates apparently consisted of amphibians and reptiles only, viz. those sent in 1854, and other promoted zoological branches may have included gastropods (terrestrial snails). Despite close contact with the MNHN, Ghiesbreght does not exist among the profiled collectors affiliated to this institution (Jaussaud \& Brygoo, 2004), highlighting the degree of indifference shown towards that notable naturalist (see also, e.g., Allorge \& Ikor, 2003). Thireau's (1986) review of the pertinent literature regarding the origin of the holotype of the salamander Speler- pes sulcatum Brocchi, i.e., Aquiloeurycea cephalicus (Cope), is a nice paradigm for the intricacy surrounding $A B G$ specimens at large.

Nota 21. Tulasne (1855) described the original series of Citriosma riparia (coll. "Ghiesbrecht" and Galeotti) from "Nova Hispania (Huatusco, Jalapa, Mirador, etc.)". Huatusco is also the type locality of, for instance, the orchid Todaroa micrantha Richard \& Galeotti, 1845, i.e., Campylocentrum schiedei (Rchb. f.) Benth. ex Hemsley, 1883 (holotype MNHN-P 361634, ABG 113). Further origins of "Oaxaca" plants collected by Ghiesbreght in 1842 include, for example, Totutla in Veracruz (Miconia tococoides Naudin, 1851 [M. mexicana (Bonpl.) Naud.], syntypes MNHNP 506170-71), Huitzilac ("Huichilaque") in extreme N Puebla (Eryngium ghiesbreghtii Decaisne, 1873, MNHN-P 834323), and Zacualtipán in Hidalgo (Chaetogastra [Tibouchina] naudiniana Decaisne, 1847, isotype MNHN-P 708713) as noted elsewhere (Sources and Material). Also, the fern Pteris [Mildella] intramarginalis Kaulfuss ex Link, 1833 from Metztitlán ("pr. Mextillan”, Fournier 1872: 116; e.g., Martens \& Galeotti, 1843: 222) was obtained in Hidalgo. Species from the vicinity of Tlacolula found in April 1842 such as Asplenium ghiesbreghtii Fournier, 1872 (p. 111, Pl. 5, see Fig. 2) originate from inland northern Veracruz, and not the homonymic place close to Oaxaca de Juárez (Fig. 1). Other ferns (ABG) are from the "valle Mexicensi" (1.c.: 77) and "in alta planitie Mexicana, ad rupes pr. montem ignivonium Tapmaroa" (1.c.: 133), viz. Ciudad Hidalgo (formerly Tajimaroa) in Michoacán, as is the case with Viguiera ghiesbreghtii Gray, 1884 (Asteraceae) from "pine forests near Morelia" (n 381).

Nota 22. Helicina lindeni Pfeiffer, 1849 from "Tapinaba, Mexico (Linden)", a junior synonym of $H$. tenuis Pfeiffer, 1849 fide van Martens (1890), is based on an unknown number of specimens collected by Ghiesbreght's early companion in Mexico (18381840) and acquired by H. Cuming. We cannot properly identify this place name nor "Tapinapa" (e.g., Pfeiffer, 1852; Fischer \& Crosse, 1893) and it is worthwhile mentioning that Liebmann (see above in main text) collected plants at San Pedro Tepinapa, Oaxaca, in summer 1842 (e.g., Fournier, 1886). Although Cuming's snails were later incorporated into the BMNH collection, the type material of $H$. lindeni is not stored there (J. Ablett in litt.). It may have become part of Pfeiffer's private collection which is largely lost (Richling \& Glaubrecht, 2008), thus making it impossible to decipher the handwriting on the original label, verify the correct spelling of the type locality, or exclude a potential confusion of the patronymic collector (e.g. "Liebm." instead of “Lind."). 